\title{
Kingdom of the Netherlands-Aruba: Detailed Assessment of Compliance with the Basel Core Principles for Effective Banking Supervision
}

This Detailed Assessment of Compliance with the Basel Core Principles for Effective Banking Supervision for the Kingdom of the Netherlands-Aruba was prepared by a staff team of the International Monetary Fund. It is based on the information available at the time it was completed in May 2008. The views expressed in this document are those of the staff team and do not necessarily reflect the views of the government of the Kingdom of the Netherlands-Aruba or the Executive Board of the IMF.

The policy of publication of staff reports and other documents by the IMF allows for the deletion of market-sensitive information.

Copies of this report are available to the public from

International Monetary Fund $\bullet$ Publication Services

700 19th Street, N.W. • Washington, D.C. 20431

Telephone: (202) 6237430 • Telefax: (202) 6237201

E-mail: publications@imf.org • Internet: http://www.imf.org

Price: $\$ 18.00$ a copy

\section{International Monetary Fund Washington, D.C.}





\section{OfFShore Financial Center Assessment Program ARUBA}

DETAILED ASSESSMENTS OF COMPLIANCE WITH THE BASEL CORE PRINCIPLES FOR EFFECTIVE BANKING SUPERVISION

MAY 2008 
Table of Contents

Detailed Assessment of Compliance with the Basel Core Principles for Effective Banking

Supervision

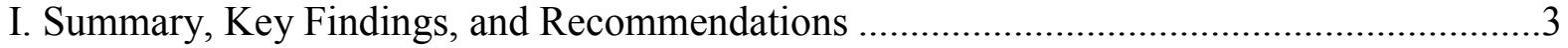

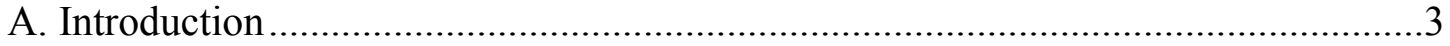

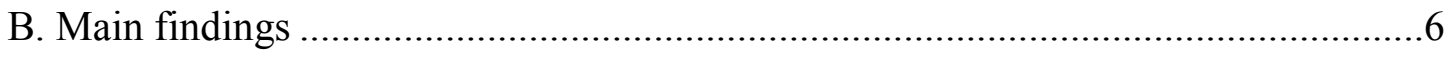

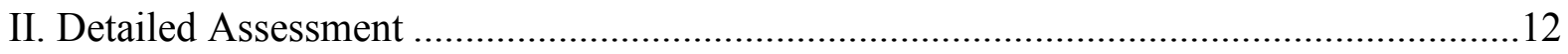

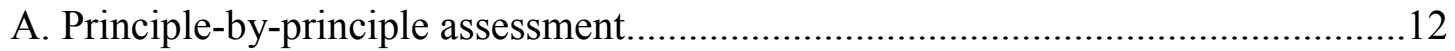

Tables

1. Summary Compliance with the Basel Core Principles_-Detailed Assessments ..................8

2. Recommended Action Plan to Improve Compliance with the Basel Core Principles .........11

3. Detailed Assessment of Compliance with the Basel Core Principles ................................13 


\section{Detailed Assessment of Compliance with the Basel Core Principles for EFFECTIVE BANKING SUPERVISION}

\section{Summary, Key Findings, AND RECOMMENDATIONS}

\section{A. Introduction}

1. With the concurrence of the Central Bank of Aruba (CBA), the mission assessed compliance with the 2006 revised Basel Core Principles for Effective Banking Supervision using the Core Principles Methodology (see Table 3). Compliance with both the essential and additional criteria was assessed at the request of the CBA. The assessment was based on the CBA's self assessment of compliance with the Core Principles, a review of the relevant laws and regulations, interviews with the staff of CBA and discussions with auditors and onshore and offshore banks. The assessors were Socorro Heysen (Consultant) and Gabriella Ferencz, Lead Financial Sector Specialist (World Bank).

\section{Information and methodology used for assessment}

2. The CBA prepared a detailed self-assessment and filled out the questionnaires in preparation for the OFC. The mission was provided with the relevant laws, regulations, policy notes, reporting forms and onsite and offsite inspection reports.

3. The assessors conducted meetings with senior supervisory staff, as well as junior supervisory staff as appropriate, as well as President of the Central Bank. The assessors also had discussions with onshore and offshore banks, the Auditor's Association of Aruba and the RCUT, Aruba's FIU. The work of the assessors was greatly facilitated by the thorough and candid self assessment conducted by the authorities.

\section{Institutional and macroeconomic setting and market structure—overview}

4. The banking sector in Aruba is comprised of four domestic commercial banks, banklike financial institutions, and offshore banks. The commercial banks are mainly engaged in domestic lending. The products and services of the commercial banks are mainly in the traditional retail sector, with interest on domestic credit remaining the predominant source of income. The assets of the commercial banks are mainly funded via resident deposits and savings. Only a small percentage of the total deposits are non-resident, foreign currency.

5. Of the four commercial banks, one is a branch of a commercial bank domiciled in Curaçao, Netherlands Antilles, while the other three banking institutions are subsidiaries of banks established in Curaçao, Netherlands Antilles. Therefore, all four commercial banks operating in Aruba are also supervised on a consolidated basis by the Bank of the Netherland Antilles. Two of the Curaçao incorporated parent banks are, themselves, owned or in the process of being acquired by internationally active Canadian banks. The other two parents are owned by private interests. 
6. The banking sector has been stable over the years. It is largely ( 80 percent) reliant on tourism and services related to tourism. The activities of the domestic commercial banks and the non-bank financial sector are mainly domestic. The main source of financial system risk remains the one-sided structure of the Aruban economy. The potential risks for commercial banks operating in a small and undiversified economy are quite high. Therefore, they must maintain sufficient reserves to absorb possible losses stemming from economic downturns. For that reason, CBA decided to increase the minimum risk-weighted capital assets ratio for banks from 10 to 12 percent, effective January 1, 2007. Branches or subsidiaries of international banks that fall under consolidated supervision are allowed to maintain a minimum risk-weighted assets ratio of 8 percent. For bank-like financial institutions and institutional investors the one-sided economy also remains the most important source of risk.

7. Aruba's offshore banking sector is very small by international standards, with only two institutions registered. These banks are solely engaged in banking activities to nonresidents. The two offshore banks are both affiliated with Citibank, N.A, of the US, one being a subsidiary and the other a branch, and are also supervised, on a consolidated basis, by the Office of the Comptroller of the Currency and the Federal Reserve Board, respectively. Of the two offshore banks, one is mainly engaged in intragroup financing and the financing of sovereign bonds, while the other's activities relate to the trading and financing of Latin American sovereign risk bonds and loans, underwriting of bonds and shares for customers and other general banking services. There is no physical presence in Aruba. The management and administration is conducted by Citibank, Venezuela. They function as administrative booking offices. They originally chose to establish themselves in Aruba because of its political and financial stability, convenient location and low taxation. Note also that Citibank N.A. has decided to remain with only one offshore entity in Aruba in due time, namely Citibank Aruba N.V. In this regard, the balance sheet of Citibank N.A. Aruba Branch has been decreasing over the past few years and will continue to decrease in coming years.

8. To date, the CBA has not conducted on-site examinations of the offshore banks. The mission recommends that they carry out their plan to hire external auditors to perform an examination on a number of risk areas. The mission also recommends that the CBA meet with management as soon as possible to better understand their plans for their Aruban operations and their financial results. They should be subject to the same level of supervision as the onshore banks and should provide periodic offsite reports to the CBA. The offshore banks essentially operate as shell banks and shell banks are generally not appropriate for jurisdictions. Given that the CBA does not exercise supervision over the operations, there is reputational risk to Aruba and the CBA should problems arise. Should the offshore banks not comply with the CBA requirements, the CBA may want to consider closing them to avoid unnecessary risk.

9. The size of bank-like financial institutions is very small in terms of balance sheet total. This sub-sector consists of FCCA, AIB and Island Finance N.V. These institutions are engaged predominantly in mortgage lending to individuals, financing of social housing projects, long-term project financing and/or granting of personal loans for consumptive and home improvement purposes. Their loans represent nearly 20 percent of the housing loan market in Aruba, but their market share has fallen in recent years. These activities are financed largely through funds obtained from their parent company, other (local) financial 
institutions, and/or institutional investors. Bank-like institutions are not allowed to attract deposits from the public.

\section{Overall Supervisory and Regulatory Framework}

10. CBA supervises banks, money transfer companies, insurance companies and company pension funds on the basis of the respective state ordinances regulating these sectors. CBA is an autonomous entity. The President of CBA, assisted by two executive directors, determines the policies of CBA. The President is appointed on the recommendation of the Supervisory Board for an indefinite period by the Governor of Aruba, who is the representative of the Queen of the Netherlands. Only the Governor, on the recommendation of the Supervisory Board, can approve the President's dismissal. The political responsibility for the execution of CBA's tasks lies with the Minister of Finance. No operational guidance is given to CBA by the Minister. It is fully independent in setting monetary and prudential policy.

11. CBA is also independent from the Government's budgetary process. Its main source of income is generated from the investments of the official foreign exchange reserves of Aruba, which it holds. After financing its operations, including the supervisory activities, this source of income still leaves CBA with an annual profit, demonstrating that it has sufficient financial resources. In view of the continuous expansion and strengthening of the supervisory framework and increasing associated costs it is in the process of charging (part of) the supervision costs to the sectors supervised. At present, only insurance and money transfer sectors are charged in part for the supervisory costs incurred. It is the intention to also charge the banking and pension fund sectors in due time for the supervision costs incurred. In this respect, draft state decrees have been submitted to the government for review and approval.

12. CBA's supervision department, which falls under the responsibility of the executive director in charge of supervision, consists of 10 staff members, supported by one secretary. The average supervisory experience is about seven years, and there is currently one vacancy for a senior staff member. Both the director and all the staff members hold university or bachelors degrees, obtained either in the Netherlands (six persons), the United States (two persons) and Aruba (two persons). The general manager is a Dutch-trained certified public accountant with a number of years of experience in auditing financial institutions while the manager of the supervision department holds a Fellow Life Management Institute title (a US degree in the area of insurance management) and is knowledgeable in supervisory regulation and policy matters. In addition, two staff members hold an ACAMS certification.

13. Given the increasing responsibilities that the CBA is taking on it should periodically reassess the adequacy of its resources and staffing to do so. A more risk based approach to supervision could result in less time as there would be better analysis of operations. Technical assistance in improving reporting forms would quicken the pace of the move toward risk based supervision.

14. The legal and regulatory framework is generally adequate for the conduct of banking supervision. There are several proposals in preparation to strengthen the supervisory laws for banking and insurance which would strengthen the ability of the supervisory authority to 
carry out its function. The accounting standards are good and banks are required to have an external audit annually. Disclosure needs some enhancement. There is a lack of transparency given the limited availability of financial reports. There should also be disclosure about the qualitative elements of banks' operations, as part of their financial results.

\section{Preconditions for effective banking supervision}

15. The preconditions for effective banking supervision exist to a large extent although enhancements are needed as pointed out herein. Macroeconomic policies are generally sound. Aruba remains one of the most developed islands in the region. This is a result of its market friendly policies that have fostered a stable macroeconomic environment and a rapid expansion of the tourist sector. As important, Aruba remains open to foreign investment and migrant workers, who make up 40 percent of the population have been key contributors to economic growth.

16. The economy continues to be at risk from external factors. The economy and hence the commercial banking sector are highly dependent on tourism, mostly from the U.S. Public infrastructure is well developed and supports the conduct of banking supervision. Accounting standards are high, collateral is accessible, and the judicial system is functioning and supportive of the conduct of banking supervision. Although it is a small economy, there is effective market discipline. Market discipline would be enhanced by more disclosure of banks' financial results as well as qualitative information about their operations.

\section{B. Main findings}

\section{Objectives, independence, powers, transparency, and cooperation (CP 1)}

17. Four of the six elements of CP 1 were found to be compliant. CP 1(4) was also found to be largely compliant. The powers to address compliance will be greatly enhanced by the passage of the draft law granting the CBA the authority to levy fines, sanctions, and/or administrative penalties to banks, management and board members in the event of noncompliance. CP 1(5) was found to be largely compliant. There is no explicit mention in the law of protection of supervisory staff. The CBA sought legal advice from the Dutch Central Bank on this matter. According to their advice, the Dutch legal system, on which Aruban laws are based, the employer is responsible for the actions of its employees.

\section{Licensing and structure (CPs 2-5)}

18. These criteria were found to be compliant. Licensing criteria are sufficiently broad. No new licenses have been granted for years although there are periodic inquiries. The law adequately defines significant ownership and controlling interest. Although the legal requirements to obtain supervisory approval for proposed changes in ownership and control are adequate, they would benefit from clarification regarding multiple acquisitions below the threshold that could in sum total in excess of the thresholds for notification. The CBA has adequate criteria for reviewing major acquisitions or investments by banks. 


\section{Prudential regulation and requirements (CPs 6-18)}

19. Some prudential regulations and requirements are adequate and others need improvement. Implementation needs improvement in a number of areas as well.

- $\quad$ CP 6 regarding capital adequacy was found to be largely compliant. The CBA sets the minimum regulatory capital for banks at 12 percent and they all meet or exceed the minimum. However, while the CBA contends that market risk is not an issue for onshore banks it is believed that the offshore banks have trading desks and therefore are exposed to market risk. Market risk needs to be supervised by the CBA at the offshore banks.

- $\quad$ CP 7 regarding risk management was found to be materially non compliant. Supervision continues to be largely compliance based. The CBA needs to enhance its ability to conduct risk based supervision and it must work closely with banks so that they incorporate risk management into their operations.

- $\quad$ CP 8, credit risk, was found to be largely compliant. The supervisory approach to credit risk oversight is generally appropriate for the largely retail loan portfolios of commercial banks. It would be greatly enhanced by improved data and reporting from banks. This would enable the CBA to perform more meaningful financial analysis.

- $\quad$ CP 9 on problem assets, provisions and reserves was found to be largely compliant. While the focus on number of days a loan is past due is generally adequate for retail portfolios, classification of commercial loans should be more proactive and take into account qualitative factors as well.

- $\quad$ Large exposure limits, CP 10, was found to be compliant.

- $\quad$ Exposures to related parties, CP 11, was found to be largely compliant. The law should clarify that loans to companies where insiders have significant interests should be granted on no more favorable terms than other loans.

- $\quad$ CP 12, country and transfer risk, was found to be largely compliant. Even though the CBA considers these risks to be minimal, it should receive reports more frequently than once a year.

- $\quad$ CP 13, market risk was found to be noncompliant. The CBA states that this risk is small and it would be covered by the 12 percent capital charge. Market risk needs to be supervised in the offshore banks.

- $\quad$ CP 14, liquidity risk was found to be largely compliant. The required liquidity ratios and liquidity reporting requirements are in proportion to the liquidity risks in the Aruban banking sector. The industry and supervisory oversight would benefit from more proactive liquidity risk management which would address funding and contingency plans. 
- $\quad$ CP 15, operational risk, was found to be largely compliant. Certain areas that pose operational risk to banks are examined for onsite but the CBA needs to provide banks with additional guidance in this area and examine for it in greater depth.

- $\quad$ CP 16, interest rate risk, is rated materially non compliant. Interest rate risk may be small in Aruba given that loan terms regarding interest are often stated to be fixed until further notice by the bank. Some corporate loans are at fixed rates. The CBA needs to be more proactive in its supervision of interest rate risk and reporting needs to capture interest rate risk in banks to allow for a meaningful GAP analysis.

- $\quad$ CP 17, internal control and audit, and CP 18, abuse of financial services, are compliant.

\section{Methods of ongoing banking supervision (CPs 19-21)}

20. These CPs were found to be largely compliant. The supervisory approach is generally appropriate for the size and complexity of the size of the economy and the portfolios of the commercial banks. The CBA would benefit from better data from the banks to improve the information about risks in banks. Supervisory techniques are generally broad but additional analytical depth is needed. Supervisory reporting needs to be enhanced to provide more risk oriented information.

\section{Accounting and disclosure (CP 22)}

21. This CP is largely compliant. Legislative proposals are being prepared to require the CBA's prior approval in the change of its external auditors and requiring banks to publish their annual audited financial statements.

\section{Corrective and remedial powers of supervisors (CP 23)}

22. This CP is largely compliant as there are draft amendments to the banking law granting the CBA the authority to impose a tiered system of administrative fines on banks and individual managers and board members.

\section{Consolidated and cross-border banking supervision (CPs 24-25)}

23. CP 24 is not applicable as local banks to not have foreign branches or subsidiaries. CP 25 was found to be compliant.

Table 1. Aruba: Summary Compliance with the Basel Core Principles_-Detailed Assessments

\begin{tabular}{|l|c|c|}
\hline \multicolumn{1}{|c|}{ Core Principle } & Compliance & Comments \\
\hline $\begin{array}{l}\text { 1. Objectives, independence, powers, } \\
\text { transparency, and cooperation }\end{array}$ & & \\
\hline 1.1 Responsibilities and objectives & $\mathrm{C}$ & \\
\hline $\begin{array}{l}\text { 1.2 Independence, accountability and } \\
\text { transparency }\end{array}$ & $\mathrm{C}$ & \\
\hline 1.3 Legal framework & $\mathrm{C}$ & \\
\hline
\end{tabular}




\begin{tabular}{|c|c|c|}
\hline Core Principle & Compliance & Comments \\
\hline 1.4 Legal powers & LC & $\begin{array}{l}\text { There is a draft proposal in Parliament to } \\
\text { give the CBA authority to impose a tiered } \\
\text { system of administrative fines, sanctions and } \\
\text { remedial measures on banks, management } \\
\text { and board members. }\end{array}$ \\
\hline 1.5 Legal protection & LC & $\begin{array}{l}\text { While there is no explicit protection in the } \\
\text { law, Aruban law holds that the employer is } \\
\text { responsible for the actions of its employees. }\end{array}$ \\
\hline 1.6 Cooperation & $\mathrm{C}$ & \\
\hline 2. Permissible activities & $\mathrm{C}$ & \\
\hline 3. Licensing criteria & $\mathrm{C}$ & \\
\hline 4. Transfer of significant ownership & $\mathrm{C}$ & \\
\hline 5. Major acquisitions & $\mathrm{C}$ & $\begin{array}{l}\text { There should be clarification that any } \\
\text { combination of acquisitions of less than } \\
5 \text { percent that results in a } 5 \text { percent or more } \\
\text { position, needs CBA's prior approval. }\end{array}$ \\
\hline 6. Capital adequacy & LC & $\begin{array}{l}\text { Market risk at the offshore banks needs to be } \\
\text { addressed in terms of capital adequacy. }\end{array}$ \\
\hline 7. Risk management process & $\mathrm{MNC}$ & $\begin{array}{l}\text { The CBA needs to enhance its ability to } \\
\text { conduct risk based supervision and it must } \\
\text { work closely with banks so they incorporate } \\
\text { risk management into their operations. }\end{array}$ \\
\hline 8. Credit risk & $\mathrm{LC}$ & $\begin{array}{l}\text { Supervision of credit risk management would } \\
\text { be enhanced by improving the quality of data } \\
\text { which would allow for more meaningful } \\
\text { financial analysis of banks' financial results. }\end{array}$ \\
\hline 9. Problem assets, provisions, and reserves & LC & $\begin{array}{l}\text { While number of days past due is appropriate } \\
\text { for a retail portfolio, which is the bulk of } \\
\text { banks' portfolios, the CBA needs to ensure } \\
\text { that commercial loans should be classified } \\
\text { using qualitative as well as quantitative } \\
\text { criteria. }\end{array}$ \\
\hline 10. Large exposure limits & $\mathrm{C}$ & $\begin{array}{l}\text { CBA's ability to supervise would be } \\
\text { enhanced by better reporting and analysis of } \\
\text { large exposures. }\end{array}$ \\
\hline 11. Exposure to related parties & $\mathrm{LC}$ & $\begin{array}{l}\text { Loans to companies where insiders have a } \\
\text { significant interest should not be granted } \\
\text { loans on more favorable terms than non- } \\
\text { related parties. }\end{array}$ \\
\hline 12. Country and transfer risks & LC & $\begin{array}{l}\text { Reporting should be more frequent than once } \\
\text { a year. }\end{array}$ \\
\hline 13. Market risks & $\mathrm{NC}$ & $\begin{array}{l}\text { There is a need to address market risk in the } \\
\text { offshore banks. }\end{array}$ \\
\hline 14. Liquidity risk & $\mathrm{LC}$ & $\begin{array}{l}\text { The CBA needs to ensure that banks have } \\
\text { acceptable liquidity risk management } \\
\text { strategies, policies and procedures including } \\
\text { management of funding requirements and } \\
\text { contingency planning. }\end{array}$ \\
\hline 15. Operational risk & LC & $\begin{array}{l}\text { The CBA's guidance and supervision needs } \\
\text { to be in more depth. }\end{array}$ \\
\hline
\end{tabular}




\begin{tabular}{|l|c|l|}
\hline \multicolumn{1}{|c|}{ Core Principle } & Compliance & \multicolumn{1}{|c|}{ Comments } \\
\hline 16. Interest rate risk in the banking book & MNC & $\begin{array}{l}\text { Current reporting does not adequately } \\
\text { capture interest rate risk in banks although } \\
\text { the majority of loans are priced so that the } \\
\text { banks retain the right to adjust rates. }\end{array}$ \\
\hline 17. Internal control and audit & C & \\
\hline 18. Abuse of financial services & C & $\begin{array}{l}\text { The approach needs to incorporate more } \\
\text { supervision by risk including enhancing } \\
\text { reporting requirements to better reflect risks } \\
\text { in banks. }\end{array}$ \\
\hline 19. Supervisory approach & LC & $\begin{array}{l}\text { These are generally broad but additional } \\
\text { analytical depth is needed and a risk focus. }\end{array}$ \\
\hline 20. Supervisory techniques & LC & $\begin{array}{l}\text { Reports need to be enhanced to provide a } \\
\text { more risk oriented approach. }\end{array}$ \\
\hline 21. Supervisory reporting & LC & $\begin{array}{l}\text { Changes in external auditors should require } \\
\text { CBA prior approval. Qualitative information } \\
\text { regarding risk practices, strategies, etc should } \\
\text { be publicly disclosed. }\end{array}$ \\
\hline 22. Accounting and disclosure & LC & $\begin{array}{l}\text { There are proposals to enable the CBA to } \\
\text { impose a tiered system of administrative } \\
\text { fines against banks, directors, and officers in } \\
\text { the event of a breach of law or regulation. } \\
\text { These should be expanded to include the } \\
\text { ability of the CBA to impose fines if the } \\
\text { banks act in an unsafe and unsound manner. }\end{array}$ \\
\hline $\begin{array}{l}\text { 23. Corrective and remedial powers of } \\
\text { supervisors }\end{array}$ & C & NA \\
\hline 24. Consolidated supervision & 25. Home-host relationships & L \\
\hline
\end{tabular}

Aggregate: Compliant (C) - 12, Largely Compliant (LC) - 14, Materially Non-Compliant (MNC) - 2, NonCompliant (NC) - 1, Not Applicable (N/A) - 1 


\section{Recommended action plan and authorities' response}

\section{Recommended action plan}

Table 2. Aruba: Recommended Action Plan to Improve Compliance with the Basel Core Principles

\begin{tabular}{|c|c|}
\hline Reference Principle & Recommended Action \\
\hline 1.4 Legal powers & $\begin{array}{l}\text { Issue draft proposal to give the CBA authority to } \\
\text { impose a tiered system of administrative fines, } \\
\text { sanctions and remedial measures on banks, } \\
\text { management and board members. Current draft should } \\
\text { be expanded to include the ability of the CBA to } \\
\text { impose fines if the banks act in an unsafe and unsound } \\
\text { manner. }\end{array}$ \\
\hline CP 5 Major acquisitions & $\begin{array}{l}\text { There should be clarification that any combination of } \\
\text { acquisitions of less than } 5 \text { percent that results in a } \\
5 \text { percent or more position, needs CBA's prior } \\
\text { approval. }\end{array}$ \\
\hline CP 6 Capital adequacy & $\begin{array}{l}\text { Market risk at the offshore banks needs to be } \\
\text { addressed in terms of capital adequacy. }\end{array}$ \\
\hline CP 7 Risk Management Process & $\begin{array}{l}\text { The CBA needs to enhance its ability to conduct risk } \\
\text { based supervision and it must work closely with banks } \\
\text { so they incorporate risk management into their } \\
\text { operations. }\end{array}$ \\
\hline CP 8 Credit Risk & $\begin{array}{l}\text { Supervision of credit risk management would be } \\
\text { enhanced by improving the quality of data which } \\
\text { would allow for more meaningful financial analysis of } \\
\text { banks' financial results. }\end{array}$ \\
\hline CP 9 Problem Assets, provisions and reserves & $\begin{array}{l}\text { While number of days past due is appropriate for a } \\
\text { retail portfolio, which is the bulk of banks' portfolios, } \\
\text { the CBA needs to ensure that commercial loans should } \\
\text { be classified using qualitative as well as quantitative } \\
\text { criteria. }\end{array}$ \\
\hline CP 10 Large exposure limits & $\begin{array}{l}\text { CBA's ability to supervise would be enhanced by } \\
\text { better reporting and analysis of large exposures. }\end{array}$ \\
\hline CP 11 Exposure to related parties & $\begin{array}{l}\text { Loans to companies where insiders have a significant } \\
\text { interest should not be granted loans on more favorable } \\
\text { terms than non-related parties. }\end{array}$ \\
\hline CP 12 Country and transfer risks & Reporting should be more frequent than once a year. \\
\hline CP 13 Market Risk & $\begin{array}{l}\text { There is a need to address market risk in the offshore } \\
\text { banks. }\end{array}$ \\
\hline CP 14 Liquidity risk & $\begin{array}{l}\text { The CBA needs to ensure that banks have acceptable } \\
\text { liquidity risk management strategies, policies and } \\
\text { procedures including management of funding } \\
\text { requirements and contingency planning. }\end{array}$ \\
\hline CP 15 Operational risk & $\begin{array}{l}\text { The CBA's guidance and supervision needs to be in } \\
\text { more depth. }\end{array}$ \\
\hline CP 16 Interest Rate Risk in the banking book & $\begin{array}{l}\text { Current reporting needs to be enhanced to adequately } \\
\text { capture interest rate risk in banks although the majority } \\
\text { of loans are priced so that the banks retain the right to } \\
\text { adjust rates. }\end{array}$ \\
\hline
\end{tabular}




\begin{tabular}{|l|l|}
\hline \multicolumn{1}{|c|}{ Reference Principle } & \multicolumn{1}{|c|}{ Recommended Action } \\
\hline CP 19 Supervisory Approach & $\begin{array}{l}\text { The approach needs to incorporate more supervision } \\
\text { by risk including enhancing reporting requirements to } \\
\text { better reflect risks in banks. }\end{array}$ \\
\hline CP 20 Supervisory Techniques & $\begin{array}{l}\text { These are generally broad but additional analytical } \\
\text { depth is needed and a greater risk focus. }\end{array}$ \\
\hline CP 21 Supervisory reporting & $\begin{array}{l}\text { Reports need to be enhanced to provide a more risk } \\
\text { oriented approach. }\end{array}$ \\
\hline CP 22 Accounting and disclosure & $\begin{array}{l}\text { Changes in external auditors should require CBA prior } \\
\text { approval. Qualitative information regarding risk } \\
\text { practices, strategies, etc should be publicly disclosed. }\end{array}$ \\
\hline CP 23 Corrective and remedial powers of supervisors & $\begin{array}{l}\text { There are proposals to enable the CBA to impose a } \\
\text { tiered system of administrative fines against banks, } \\
\text { directors, and officers in the event of a breach of law or } \\
\text { regulation. These should be expanded to include the } \\
\text { ability of the CBA to impose fines if the banks act in an } \\
\text { unsafe and unsound manner. }\end{array}$ \\
\hline
\end{tabular}

\section{Authorities' response to the assessment}

24. The authorities indicated that although on certain issues their views differ slightly from those of the mission, they are of the opinion that such reports are well balanced and give a detailed view of the areas that need further improvement. They were also pleased that the report acknowledged the progress made since the last assessment and the ongoing efforts to strengthen the legal framework and supervisory practices. The authorities stressed their intention to follow up swiftly on the recommendations made in the report and, in this regard, a detailed action plan for furthering compliance with the BCPs will be prepared on short term, also taking into account the action plan recommended in the assessment. The authorities also indicated that they intend to submit a request for technical assistance of the Dutch Central Bank in the areas that need further strengthening, particularly on risk management and risk based supervision. They also noted that they would appreciate receiving Fund technical assistance to conduct a stress test on the resilience of the financial system.

\section{Detailed Assessment}

\section{A. Principle-by-principle assessment}

25. The assessment of compliance of each principle was made based on the following four-grade scale: compliant, largely compliant, materially noncompliant, and noncompliant.

- Compliant - A country will be considered compliant with a Principle when all essential criteria applicable for this country are met without any significant deficiencies. There may be instances, of course, where a country can demonstrate that the Principle has been achieved by other means. Conversely, due to the specific conditions in individual countries, the essential criteria may not always be sufficient to achieve the objective of the Principle, and therefore other measures may also be 
needed in order for the aspect of banking supervision addressed by the Principle to be considered effective.

- $\quad$ Largely compliant - A country will be considered largely compliant with a Principle whenever only minor shortcomings are observed which do not raise any concerns about the authority's ability and clear intent to achieve full compliance with the Principle within a prescribed period of time. The assessment "largely compliant" can be used when the system does not meet all essential criteria, but the overall effectiveness is sufficiently good, and no material risks are left unaddressed.

- Materially non-compliant - A country will be considered materially non-compliant with a Principle whenever there are severe shortcomings, despite the existence of formal rules, regulations and procedures, and there is evidence that supervision has clearly not been effective, that practical implementation is weak, or that the shortcomings are sufficient to raise doubts about the authority's ability to achieve compliance. It is acknowledged that the "gap" between "largely compliant" and "materially non-compliant" is wide, and that the choice may be difficult. On the other hand, the intention has been to force the assessors to make a clear statement.

- $\quad$ Non-compliant - A country will be considered non-compliant with a Principle whenever there has been no substantive implementation of the Principle, several essential criteria are not complied with or supervision is manifestly ineffective.

26. In addition, a Principle will be considered not applicable when, in the view of the assessor, the Principle does not apply given the structural, legal and institutional features of a country.

Table 3. Aruba: Detailed Assessment of Compliance with the Basel Core Principles

\begin{tabular}{|ll|}
\hline Principle 1. & Objectives, independence, powers, transparency, and cooperation \\
& $\begin{array}{l}\text { An effective system of banking supervision will have clear responsibilities } \\
\text { and objectives for each authority involved in the supervision of banks. } \\
\text { Each such authority should possess operational independence, transparent } \\
\text { processes, sound governance and adequate resources, and be accountable for } \\
\text { the discharge of its duties. A suitable legal framework for banking supervision } \\
\text { is also necessary, including provisions relating to authorization of banking } \\
\text { establishments and their ongoing supervision; powers to address compliance } \\
\text { with laws as well as safety and soundness concerns; and legal protection for } \\
\text { supervisors. Arrangements for sharing information between supervisors and } \\
\text { protecting the confidentiality of such information should be in place. }\end{array}$ \\
\hline Principle 1(1) & $\begin{array}{l}\text { Responsibilities and objectives } \\
\text { An effective system of banking supervision will have clear responsibilities } \\
\text { and objectives for each authority involved in the supervision of banks. }\end{array}$ \\
\hline Description & Essential criteria \\
\hline
\end{tabular}




\begin{tabular}{|c|c|}
\hline & $\begin{array}{l}\text { 1. The Central Bank of Aruba (CBA) is solely responsible for the supervision } \\
\text { of banks in Aruba. Its responsibilities and objectives are detailed in the Central } \\
\text { Bank Ordinance (AB 1991 No. GT 32) and the Supervision of the Credit } \\
\text { System (AB 1998 No. 16) (SOSCS). The SOSCS is mainly based on the Dutch } \\
\text { Act on the Supervision of the Credit System of } 1992 \text {. The SOSCS, together } \\
\text { with supporting prudential regulations, provide a framework of minimum } \\
\text { standards that banks must meet. Reference to these objectives is made in the } \\
\text { annual reports and } 4{ }^{\text {th }} \text { Quarterly Bulletin of CBA, as well as its website. } \\
\text { 2. Laws and supporting regulations provide a framework of minimum } \\
\text { prudential standards that banks must meet. In its supervisory function, CBA } \\
\text { monitors compliance with laws and regulations, monitors solvency and liquidity } \\
\text { through off-site surveillance and on-site inspections, and has issued various } \\
\text { supervisory directives, guidelines, and policy papers. } \\
\text { 3. Proposals for legislative changes are initiated and prepared by CBA, } \\
\text { in consultation with the representative organization, and are submitted to the } \\
\text { Minister of Finance. Upon his approval, the proposals are sent to the } \\
\text { Government Legal \& Legislative Department. Proposals become effective after } \\
\text { they have been evaluated by the advisory council and enacted by Parliament. } \\
\text { CBA is currently in the process of drafting proposals to strengthen both the } \\
\text { SOSCS and the SOSIB. } \\
\text { 4. In accordance with Section } 50 \text { of the SOSCS, a report is submitted annually } \\
\text { to the Minister of Finance, in which he is informed of the most important } \\
\text { supervisory developments over the prior year. CBA's annual report includes } \\
\text { relevant supervisory developments and aggregated key financial data of the } \\
\text { supervised institutions. The annual reports, together with quarterly bulletins, } \\
\text { provide published information about the financial strength and performance of } \\
\text { the financial sector. All information is also available on CBA's website. } \\
\text { Additional Criteria: } \\
\text { banks/banking groups. Note in this respect that the four commercial banks, due } \\
\text { to the systemic risk they represent, are subject to annual on-site examinations. } \\
\text { Each bank also receives an overall grading based upon the risk assessment } \\
\text { performed. }\end{array}$ \\
\hline Assessment & Compliant \\
\hline \multicolumn{2}{|l|}{ Comments } \\
\hline Principle 1(2) & $\begin{array}{l}\text { Independence, accountability and transparency } \\
\text { Each such authority should possess operational independence, transparent } \\
\text { processes, sound governance and adequate resources, and be accountable for } \\
\text { the discharge of its duties. }\end{array}$ \\
\hline Descr & Essential c \\
\hline
\end{tabular}


1. CBA is a legal entity in itself (sui generis) with an autonomous position within Aruba's public sector. No operational guidance is given to CBA by the Finance Minister and it operates with no interference in its operations. The President of CBA, assisted by the executive directors, determines the policies of CBA. According to section 18 of the CBO the President and the directors are appointed for an indefinite period. Upon recommendation of the Supervisory Board of CBA, the President and directors can be suspended or dismissed by the Governor, by means of a state decree setting forth the reasons for said action. In practice, the Governor represents the Dutch queen, and to carry out a dismissal, would require Dutch authorization. No such action has been taken in the past.

2. In accordance with Section 50 of the SOSCS, a report is submitted annually to the Minister of Finance, in which he is informed of the most important supervisory developments over the prior year. CBA's annual report includes relevant supervisory developments and aggregated key financial data of the supervised institutions. The annual reports, together with quarterly bulletins, provide published information about the financial strength and performance of the financial sector. All information is also available on CBA's website.

3. The supervisory staff are professional and well regarded in the financial community. The supervision Department consists of ten persons and is supported by one secretary. The department consists of:

- 1 General Manager Supervisory Issues

- 1 Manager Supervision Department

- 2 Senior Examiners

- 3 Examiners

- 2 Junior Examiners

- 1 Legal advisor

The average supervisory experience is about seven years. There is currently one vacant position for a senior examiner. All staff members hold Bachelors or Masters degrees, in business economics, accountancy, economics, public administration and civil law obtained either in the Netherlands (seven persons), the U.S. (two person), and Aruba (two persons). The general manager is a Dutch-trained certified public accountant with experience in auditing financial institutions, gained partly in the Netherlands, while the manager of the Supervision Department also holds the FMLI title. Both the general manager and manager have about 15 years experience in supervision.

4. CBA is independent from the Government's budgetary process. It is funded independently through revenue from investments of its foreign exchange reserves; revenues above those required to finance supervisory activities are used for other CBA's tasks. There are sufficient resources to provide for current operations that permit the CBA to conduct effective supervision and oversight. 


\begin{tabular}{|c|c|}
\hline & $\begin{array}{l}\text { This includes, inter alia: } \\
\text { - Salary scales that allow it to attract and retain qualified staff; } \\
\text { - A training budget and program that provides ample training } \\
\text { opportunities for staff; } \\
\text { - A budget for IT and technical support. } \\
\text { Additional resources may be required as the responsibilities of CBA expand } \\
\text { with regard to expanding supervisory responsibilities, including the supervision } \\
\text { of company service providers. } \\
\text { In view of the continuous expansion and strengthening of the supervisory } \\
\text { framework and the increasing associated costs, it is inevitable to charge (part } \\
\text { of) the supervisory costs to the sectors supervised. Until now only the insurance } \\
\text { and money transfer sectors are charged in part for the supervision costs } \\
\text { incurred. For the banking sector there is a draft regulation to charge banks for } \\
\text { part of the cost of their supervision. } \\
\text { Additional Criteria: } \\
\text { 1. The President is appointed, based on the recommendation of the Supervisory } \\
\text { Board, by the Governor of Aruba, who is the representative on Aruba of the } \\
\text { Queen of the Netherlands. Historically, the position has been offered based on } \\
\text { three year contracts with options to extend for two years. }\end{array}$ \\
\hline Assessment & Compliant \\
\hline $\begin{array}{l}\text { Comments } \\
\text { Principle 1(3) }\end{array}$ & $\begin{array}{l}\text { Legal framework } \\
\text { A suitable legal framework for banking supervision is also necessary, } \\
\text { including provisions relating to authorization of banking establishments and } \\
\text { their ongoing supervision. }\end{array}$ \\
\hline Desc & $\begin{array}{l}\text { Essential criteria: } \\
\text { 1. Under Section } 4 \text { of the SOSCS, a banking license from CBA is required, } \\
\text { prior to conducting banking activities. Once a license is granted, a credit } \\
\text { institution has to comply continuously with the licensing requirements. } \\
\text { Under Section } 11 \text { of the SOSCS, CBA has the authority to revoke a bank's } \\
\text { license. The conditions under which a bank's license can be revoked are also } \\
\text { specified in Section } 11 \text { of the SOSCS. These conditions are as follows: } \\
\text { - The credit institution so requests by registered letter; } \\
\text { - The credit institution has ceased to pursue the business of a credit } \\
\text { institution; } \\
\text { - The credit institutions does not meet the provisions under sections 2(2), } \\
7,8,22(1) \text { or }(2) \text { or } 23 \text { (1) of the SOSCS; }\end{array}$ \\
\hline
\end{tabular}




\begin{tabular}{|c|c|}
\hline & 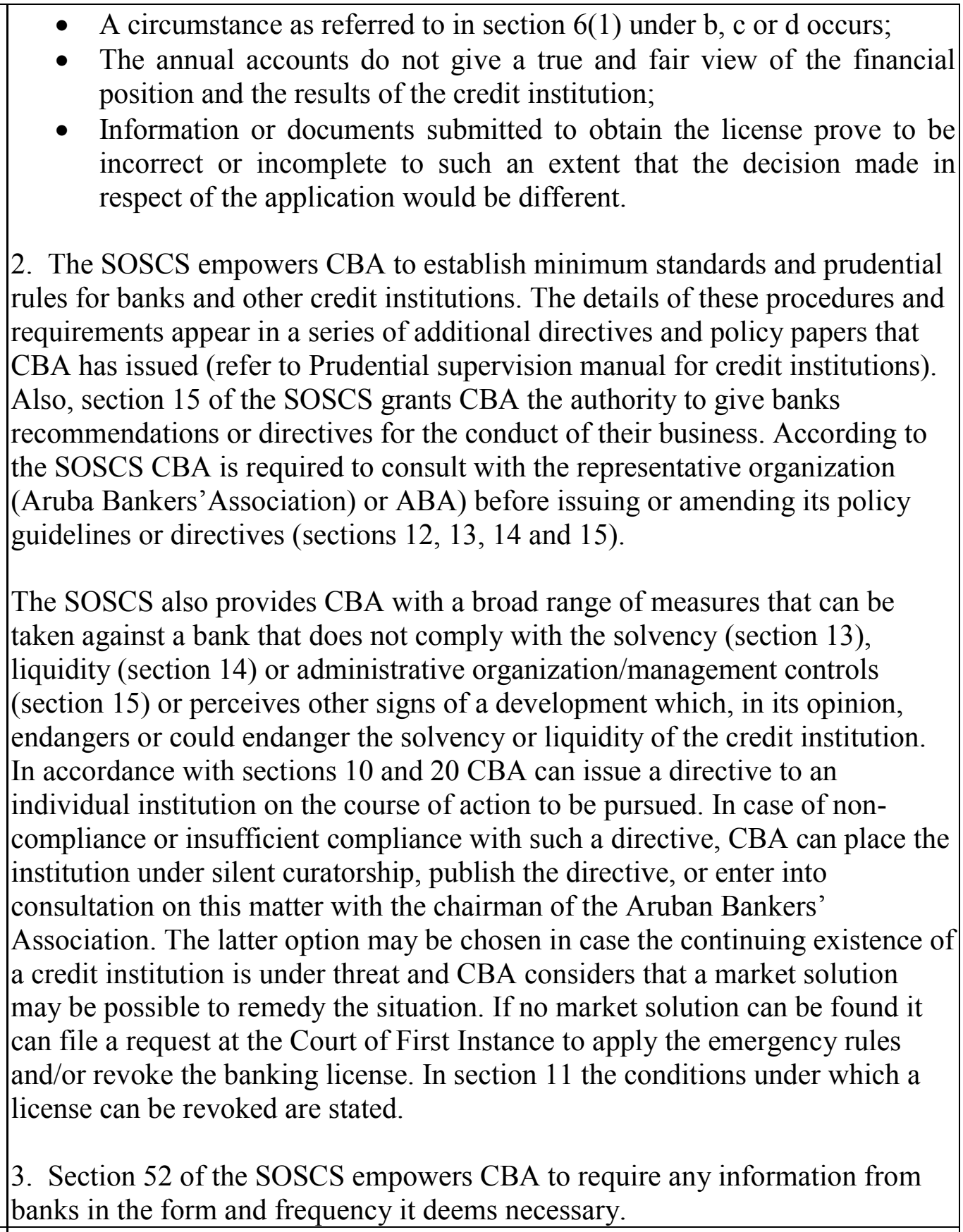 \\
\hline Assessment & Compliant \\
\hline Comments & \\
\hline Pri & $\begin{array}{l}\text { Legal powers } \\
\text { A suitable legal framework for banking supervision is also necessary, } \\
\text { including powers to address compliance with laws as well as safety and } \\
\text { soundness concerns. }\end{array}$ \\
\hline Description & $\begin{array}{l}\text { Essential criteria: } \\
\text { 1. The SOSCS provides CBA with a range of tools to address compliance with } \\
\text { the law and safety and soundness of the credit institutions under its supervision. }\end{array}$ \\
\hline
\end{tabular}




\begin{tabular}{|c|c|}
\hline & 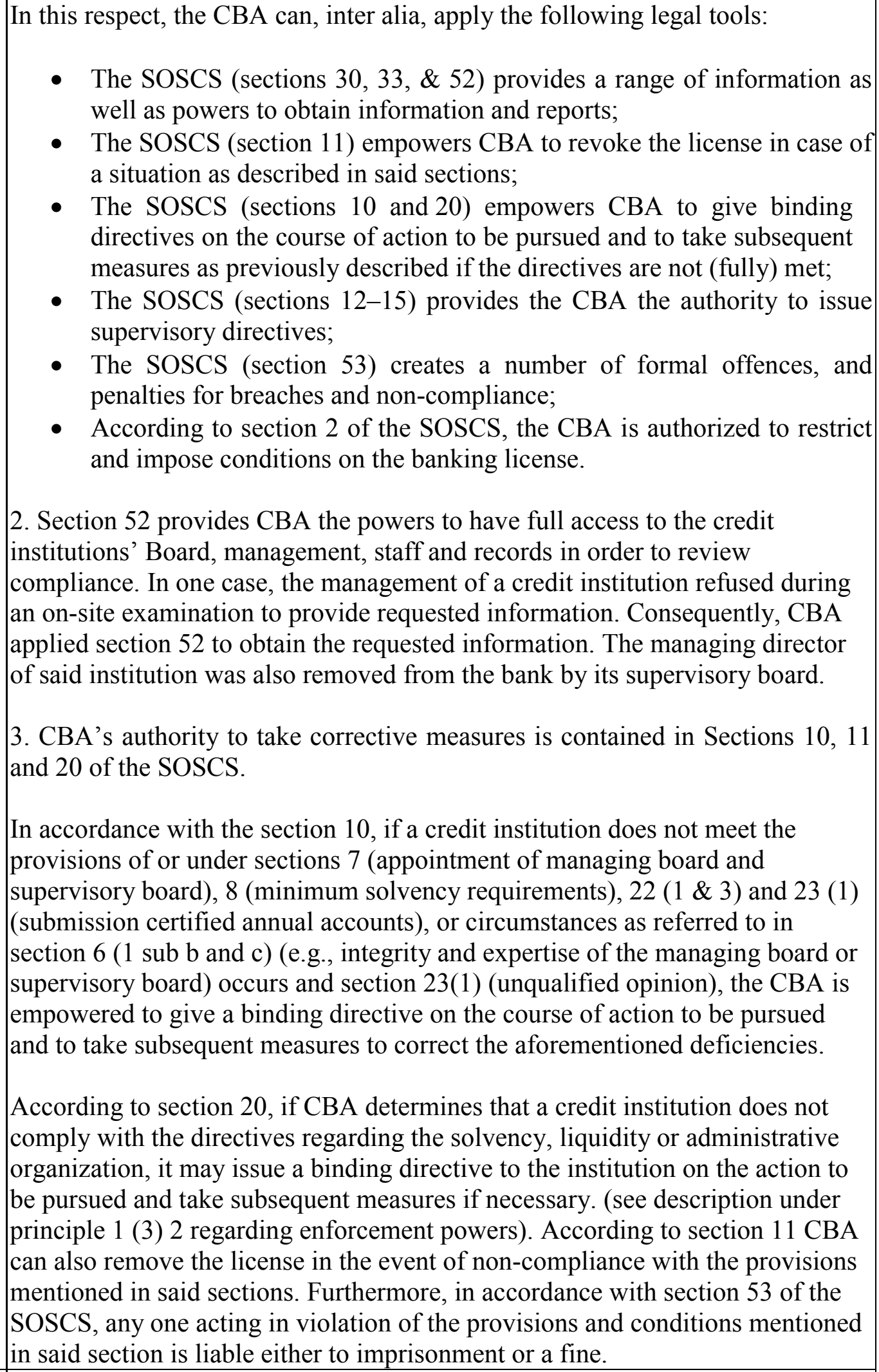 \\
\hline & Largely Compliant \\
\hline & \\
\hline
\end{tabular}




\begin{tabular}{|c|c|}
\hline & $\begin{array}{l}\text { future. This is a follow up to a recommendation made in the prior BCP } \\
\text { assessment in 2002. CBA's authority needs to be broadened to give it authority } \\
\text { to impose a tiered system of administrative fines, sanctions and remedial } \\
\text { measures on banks, as well as on individual management and supervisory board } \\
\text { members. These fines and actions should be appropriate to the level of severity } \\
\text { of either noncompliance with laws or regulations as well as with safety and } \\
\text { soundness issues. They should allow the CBA to exercise its judgment, not only } \\
\text { in terms of compliance issues, regarding the risk management of banks. }\end{array}$ \\
\hline Pril & $\begin{array}{l}\text { Legal protection } \\
\text { A suitable legal framework for banking supervision is also necessary, } \\
\text { including legal protection for supervisors. }\end{array}$ \\
\hline Desc & $\begin{array}{l}\text { Essential criteria: } \\
\text { 1. Aruban law does not contain an explicit provision with respect to the legal } \\
\text { protection of supervisory staff. Aruban civil law provides for a general tort } \\
\text { action, which can be filed against CBA or one of its employees. } \\
\text { The performance of CBA or its employees, with regard to the execution of their } \\
\text { supervisory tasks, could be brought forward to prove an alleged tort. } \\
\text { 2. There is no explicit mention in the law of the protection of the supervisory } \\
\text { agency and its staff against the costs incurred in defending their actions while } \\
\text { discharging their duties. However, it is understood to be implicit in Dutch law, } \\
\text { on which the Aruban law is based, which holds that an employer is responsible } \\
\text { for the actions of its employees in the normal conduct of their duties, if the } \\
\text { employees are acting in a responsible manner. }\end{array}$ \\
\hline Assessment & Largely compliant \\
\hline Comments & $\begin{array}{l}\text { The CBA has sought legal advice from the Dutch Central Bank on this matter. } \\
\text { According to their advice the Dutch legal system, on which also the Aruban } \\
\text { laws are based, the employer is responsible for the actions of its employees. }\end{array}$ \\
\hline Pri & $\begin{array}{l}\text { Cooperation } \\
\text { Arrangements for sharing information between supervisors and protecting the } \\
\text { confidentiality of such information should be in place. }\end{array}$ \\
\hline Desc & $\begin{array}{l}\text { Essential criteria: } \\
\text { 1. The CBA is the sole domestic authority responsible for the soundness of the } \\
\text { financial system. In matters related to AML/CFT it confers at least twice a year } \\
\text { on relevant issues. } \\
\text { 2. Section } 34 \text { of the SOSCS provides CBA with the authority to share } \\
\text { information with foreign supervisory agencies. The law also explicitly calls for } \\
\text { the safeguarding of the confidentiality of the information provided and for } \\
\text { safeguards to ensure that the information is used for the purpose for which it } \\
\text { was furnished. Section } 34 \text {, information exchange between CBA and foreign } \\
\text { supervisors, is subject to the following conditions: } \\
\text { - furnishing of the information is not contrary to the interests the SOSCS }\end{array}$ \\
\hline
\end{tabular}




\begin{tabular}{|c|c|}
\hline & $\begin{array}{l}\text { is seeking to protect; } \\
\text { - CBA has ascertained itself of the purpose for which the information } \\
\text { shall be used, and } \\
\text { it is sufficiently guaranteed that the information shall not be used for } \\
\text { other purposes; } \\
\text { - the secrecy of the information to be furnished is guaranteed; } \\
\text { - information can be exchanged on a basis of reciprocity. } \\
\text { CBA has signed two MOUs, with the BNA (Bank of the Netherland Antilles) } \\
\text { on the exchange of information on banks and insurers. BNA is the home } \\
\text { country supervisor of all four commercial banks operating in Aruba. } \\
\text { In August } 2006 \text {, CBA also became party to a Multilateral Memorandum of } \\
\text { Understanding (MMOU) on cross-border cooperation and information } \\
\text { exchange between several supervisory authorities within the Caribbean region. } \\
\text { 3. Refer to notes under criteria } 1 \text { (2). } \\
\text { 4. Section } 35 \text { of the SOSCS calls for maintaining the secrecy of information } \\
\text { obtained in the course of supervision, except as provided for in Section } 34 \text {, and } \\
\text { as called for in court orders. CBA is able to deny any request (other than a court } \\
\text { order) for confidential information in its possession in case it ascertains that the } \\
\text { foreign financial sector supervisor does not comply with the requirements } \\
\text { mentioned under section } 34 \text { of the SOSCS. To date, no request for information } \\
\text { from a foreign supervisory authority has ever been declined. }\end{array}$ \\
\hline Assessment & Compliant \\
\hline Comments & \\
\hline Pri & $\begin{array}{l}\text { Permissible activities } \\
\text { The permissible activities of institutions that are licensed and subject to } \\
\text { supervision as banks must be clearly defined and the use of the word "bank" } \\
\text { in names should be controlled as far as possible. }\end{array}$ \\
\hline Description & $\begin{array}{l}\text { Essential criteria: } \\
\text { 1. Section } 1 \text { of the SOSCS defines the term credit institution as an enterprise or } \\
\text { institution, not being CBA, whose business is to receive funds repayable on } \\
\text { demand or subject to notice being given, and to grant credits or investments for } \\
\text { its own account. Section } 2 \text { of the SOSCS states that credit institutions are } \\
\text { subject to supervision by CBA. Banking licenses set forth the allowed activities } \\
\text { and conditions to which a bank is permitted to engage in. Per Section } 2 \text { of the } \\
\text { SOSCS, CBA can place restrictions on the licenses granted with regard to the } \\
\text { type of banking activities, which are permitted. } \\
\text { 2. Section } 4 \text { of the SOSCS stipulates that no institution established in Aruba } \\
\text { can operate as a credit institution unless it has obtained a license from CBA. } \\
\text { In accordance with section } 2 \text { of the SOSCS, CBA can place restrictions on the } \\
\text { license granted with respect to, for example, the type of banking activities } \\
\text { permitted. For example, bank-like institutions operating in Aruba are not }\end{array}$ \\
\hline
\end{tabular}




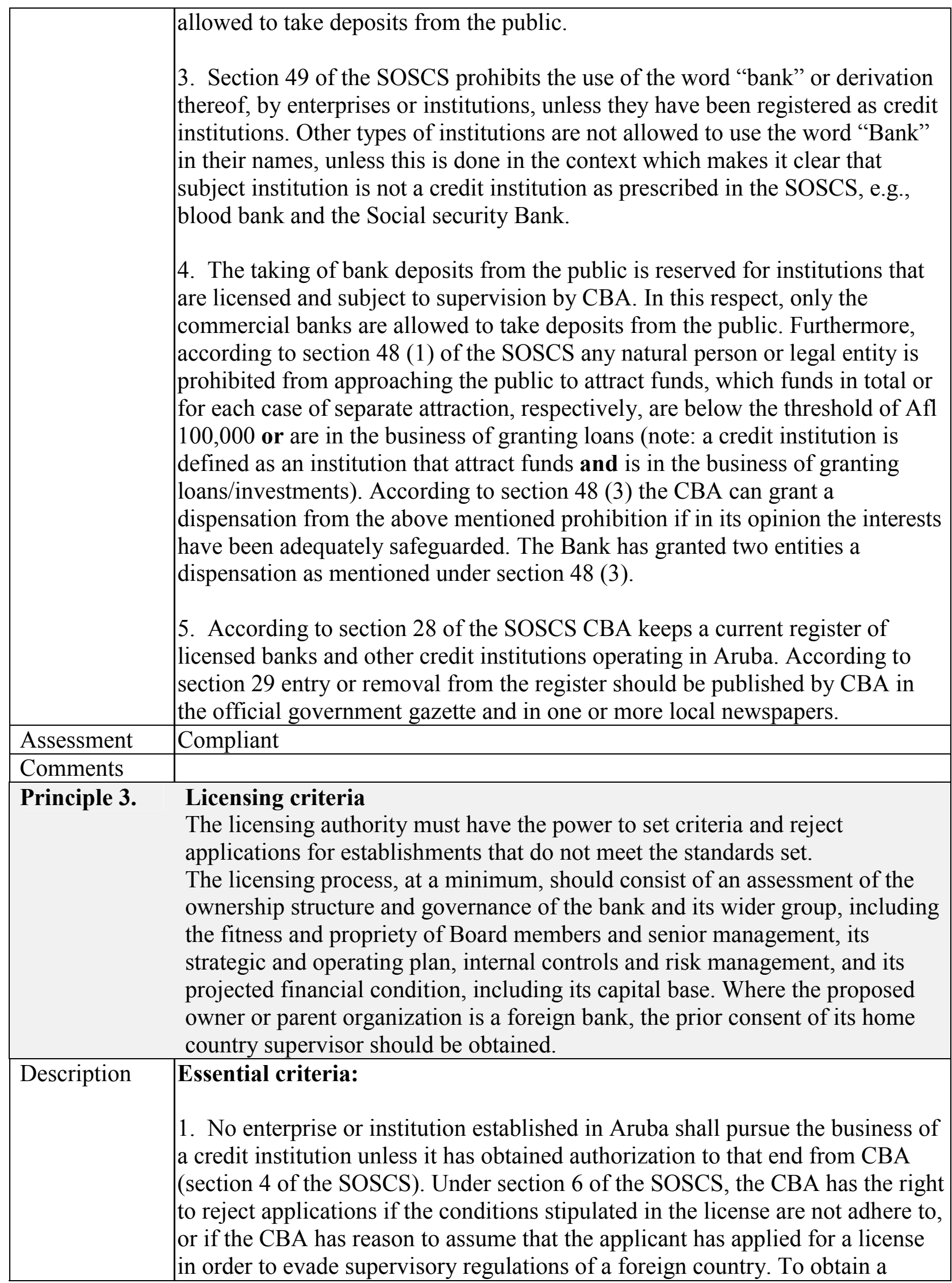


license, the institution must comply with the requirements laid down in the SOSCS (section 6). Once granted, a bank has to comply with the licensing requirements continuously.

2. The CBA set the criteria for licensing banks. The criteria which must be fulfilled to obtain a license are explicitly mentioned in section 6 of the SOSCS:

- There must be a minimum amount of own funds, which is set by State Decree at AFL 5 million (US\$ 2.8 million), and which may consist of paid-in or assigned capital and general reserves;

- Day-to-day policy should be determined by at least two persons and the supervisory board should consist of at least three persons, and CBA should be convinced that all these persons are fit and proper;

- The shareholders with a qualified holding are considered fit and proper by CBA;

- There is a certified annual report or opening balance sheet providing a true and fair view of the applicant's financial position;

- There is a sound business plan;

- Granting the license will in the opinion of CBA not lead to an undesirable development of the credit system;

- CBA has no reason to assume that the license will be used to evade supervisory regulations in another country.

In practice, CBA requires applications to include very extensive information on the proposed banking activities, including full details of ownership and related parties, detailed business plans financial projections for at least three years, details of the internal organization and control systems to be implemented.

Applications are analyzed and reviewed initially by the Supervision Department which, once all the necessary information is submitted, prepares a detailed assessment of the application and recommendation for consideration by the Bank's management.

The SOSCS licensing requirements are applicable for two types of credit institutions: credit institutions established and incorporated in Aruba (section 4), and credit institutions established outside Aruba and operate in Aruba through a branch office (section 24).

Effective January 1, 2007 the revised policy rule for admission and licensing of banks and insurance companies became effective. Under the revised policy rule, a foreign bank is only allowed to operate via a branch office if it is an international bank with a balance sheet total of at least US\$ 10 billion and has "A" rating issued by Standard \& Poor's or a comparable rating agency. Foreign banks that already operate in the Aruba market via a branch office and do not meet the aforementioned conditions are required to establish a separate legal entity in Aruba before January 1, 2008, through which they can continue their 
banking activities in Aruba.

3. Once a license is granted, a bank has to comply with the licensing requirements continuously. Section 24 sets forth banking licensing for credit institutions established outside Aruba (branch offices).

4. Under Section 6 of the SOSCS, CBA shall reject applications if the conditions stipulated in section 6 (1) subsections (a) through (g,) are not met or if CBA has reason to assume that the enterprise or institution has applied for a license in order to evade supervisory regulations of a foreign country (section 6 (2).

5. In accordance with section 6 subsections $b$, c, and d, CBA has to determine that the proposed statutory and managerial structure of the Bank will not hinder effective supervision.

6. In accordance with section 6 of the SOSCS CBA has to determine the suitability of major shareholders (qualified shareholder) with a significant interest (voting rights) and the transparency of the ownership structure. Accordance to section 1 (1) a qualifying holding is defined as a direct or indirect holding of more than 5 percent of the issued share capital of an institution or the ability to exercise directly or indirectly more than 5 percent of the voting rights in an institution, or the ability to exercise directly or indirectly a comparable degree of control in a credit institution.

7. A minimum initial capital amount is stipulated for all credit institutions under Section 8, subsection 1 of the SOSCS. By Ministerial Decree, the minimum capital requirement for credit institutions has been set at AFL 5 million (approximately US\$3 million).

8. Per Section 6, sub b and $\mathrm{c}$ of the SOSCS, CBA evaluates prospective directors and senior management as to their expertise and integrity (fit and proper test). The fit and proper criteria include (1) skills and experience in relevant financial operations commensurate with the intended activities of CBA and (2) no past record of criminal activities or adverse regulatory judgments that would make a person unfit.

9. In accordance with Section 5, sub 1e and f, the applicant has to submit a business plan, which should include the envisaged administrative, organizational and management controls, which CBA reviews in accordance with its Policy Paper on Sound Corporate Governance. The elements of the operational structure are evaluated in line with the proposed activities of CBA and continue to be ongoing supervisory requirements.

10. In accordance with Section 5 (1d) of the SOSCS, the applicant has to submit annual accounts and projections, which have been signed by an external auditor. 


\begin{tabular}{|c|c|}
\hline & $\begin{array}{l}\text { Based on these documents, CBA conducts an assessment of the adequacy of } \\
\text { financial strength to determine if it supports the proposed strategic plan. } \\
\text { Financial information is requested and reviewed on the principal shareholders. } \\
\text { 11. According to CBA's revised policy on admission and licensing of banks } \\
\text { the home country supervisor is required to provide CBA with a written } \\
\text { statement approving the establishment of the new bank and confirming that its } \\
\text { establishment will fall under the consolidated supervision of the home country } \\
\text { supervisor. The leading guideline for the Bank's policy continues to be that the } \\
\text { supervision conducted by the home country supervision meets international } \\
\text { standards. In addition, CBA must be able to exchange information with the } \\
\text { home country supervisor of the parent bank so that it can be established that the } \\
\text { home country supervision is adequate and meets international standards and the } \\
\text { parent bank meets the regulatory requirements of the home country. } \\
\text { 12. In accordance with section } 11 \text { (1) f of the SOSCS the license granted by } \\
\text { CBA can be revoked in the event that false information was provided and the } \\
\text { license would not have been provided if true information had been provided. } \\
\text { 13. The Board must have a sound knowledge of each of the types of financial } \\
\text { activities the bank intends to pursue (SOSCS section } 6 \text { sub b and c). } \\
\text { Additional Criteria: } \\
\text { 1. The assessment of the application includes the ability to supply additional } \\
\text { financial support, if needed. } \\
\text { 2. CBA monitors compliance with supervisory requirements, as well as the } \\
\text { progress of new entrants in meeting their business and strategic goals via its off- } \\
\text { site surveillance and on-site examinations. }\end{array}$ \\
\hline Assessment & Compliant \\
\hline Comments & \\
\hline & $\begin{array}{l}\text { Transfer of significant ownership } \\
\text { The supervisor has the power to review and reject any proposals to transfer } \\
\text { significant ownership or controlling interests held directly or indirectly in } \\
\text { existing banks to other parties. }\end{array}$ \\
\hline Descr & $\begin{array}{l}\text { Essential criteria: } \\
\text { 1. Section } 1 \text { of the SOSCS defines significant ownership as a direct or an } \\
\text { indirect holding of more than } 5 \text { percent of the issued share capital of an } \\
\text { enterprise or institution or the ability to exercise directly or indirectly more than } \\
5 \text { percent of the voting rights, or the ability to exercise directly or indirectly, a } \\
\text { comparable degree of control in an enterprise or institution. } \\
\text { 2. Unless prior written permission has been obtained from CBA any natural } \\
\text { person or legal entity is prohibited from acquiring or increasing a qualified }\end{array}$ \\
\hline
\end{tabular}




\begin{tabular}{|c|c|}
\hline & $\begin{array}{l}\text { holding in a bank or from exercising control. This also applies for proposed } \\
\text { changes that would result in a change of ownership or in the exercise of voting } \\
\text { rights over a particular threshold or a change in controlling interest. (SOSCS } \\
\text { Section 16, paragraph. 1b; Section 17, paragraph. 1a). } \\
\text { CBA intends to strengthen its revised policy on admission and licensing of } \\
\text { banks by including explicit requirements regarding individual shareholding. } \\
\text { The proposal is that a natural person shall not, without the approval of CBA, } \\
\text { directly or indirectly, control or hold more than } 5 \text { percent of bank's capital. } \\
\text { Furthermore, the total of individual shareholding by natural persons shall not, } \\
\text { without the approval of CBA, directly or indirectly, exceed } 25 \text { percent of the } \\
\text { total share capital. Finally, CBA will not entertain applications for licensing of } \\
\text { parallel-owned banks. These matters are now being discussed internally. } \\
\text { 3. In accordance with Sections } 16 \text { \& } 17 \text { of the SOSCS, CBA has the authority } \\
\text { to reject any proposal for a change in significant ownership or controlling } \\
\text { interest, or prevent the exercise of voting rights in such investments. } \\
\text { 4. Section } 19 \text { (2) of the SOSCS requires all credit institutions to report annually } \\
\text { all persons and companies with a qualified shareholding, as well as beneficial } \\
\text { owners of shares held by custodians. The CBA also verifies said information } \\
\text { via regular on-site examinations. } \\
\text { 5. In accordance with sections } 17 \text { (3) \& (4) CBA has the authority to modify, } \\
\text { reverse or address a change of control that has taken place without the } \\
\text { necessary notification or its approval. Moreover, it can request the Court to } \\
\text { nullify any resolution taken by shareholder(s) who were unauthorized to do so. } \\
\text { Additional Criteria: } \\
\text { 1. According to the supervisory directive on the management and reporting of } \\
\text { incidents, a credit institution must notify CBA of any incident that constitute a } \\
\text { serious risk for the integrity of the credit institution including the conduct of a } \\
\text { qualified shareholder }\end{array}$ \\
\hline Assessment & Compliant \\
\hline Comments & \\
\hline Principle 5. & $\begin{array}{l}\text { Major acquisitions } \\
\text { The supervisor has the power to review major acquisitions or investments by a } \\
\text { bank, against prescribed criteria, including the establishment of cross-border } \\
\text { operations, and confirming that corporate affiliations or structures do not } \\
\text { expose the bank to undue risks or hinder effective supervision. }\end{array}$ \\
\hline Description & $\begin{array}{l}\text { Essential criteria: } \\
\text { 1. According to section } 16(1) \text { of the SOSCS, unless it has obtained prior } \\
\text { written approval from CBA, a credit institution is prohibited from: }\end{array}$ \\
\hline
\end{tabular}




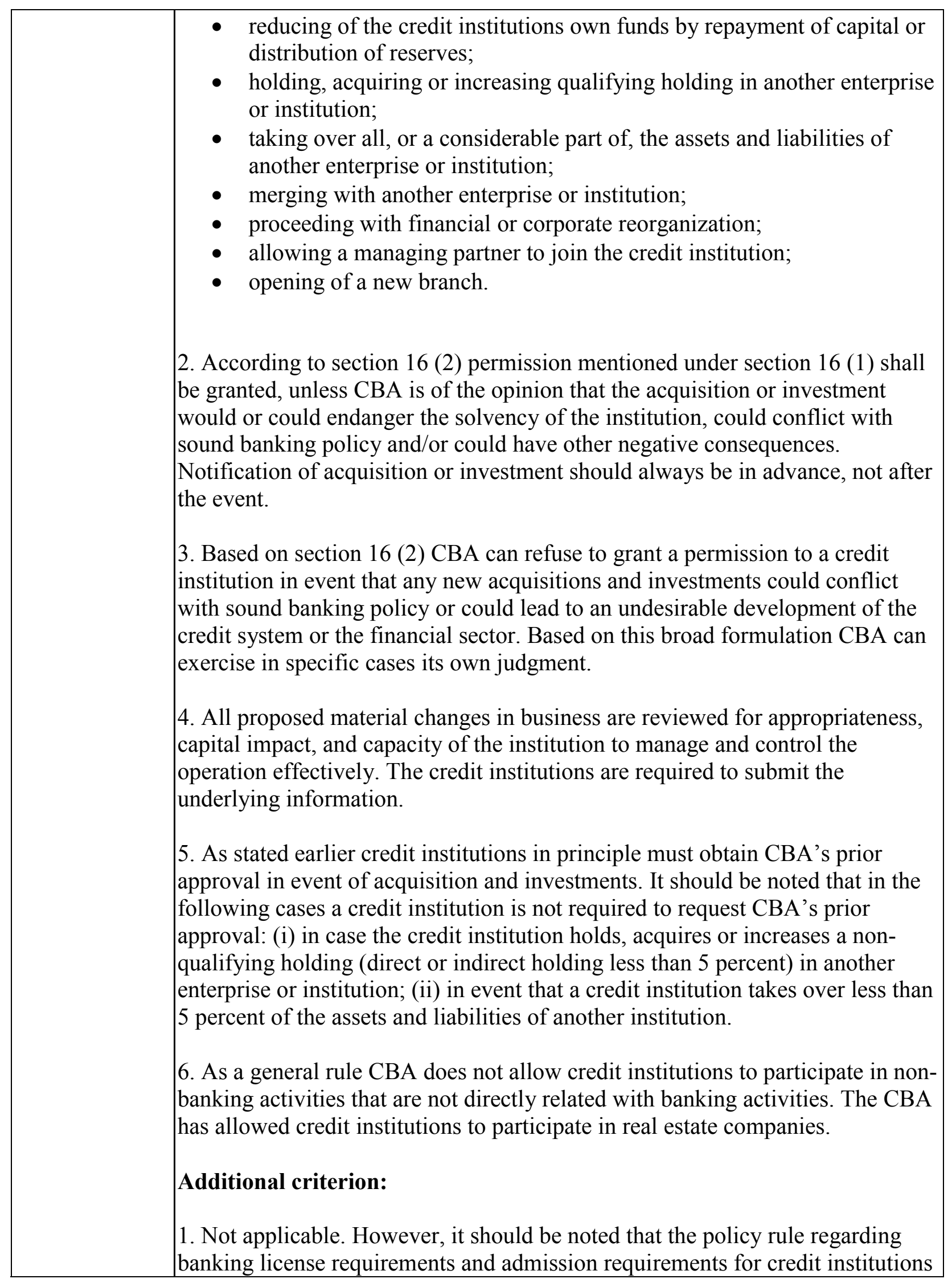




\begin{tabular}{|c|c|}
\hline & $\begin{array}{l}\text { operating in or from Aruba requires an assessment of the quality of supervision } \\
\text { in other countries. }\end{array}$ \\
\hline Assessment & Compliant \\
\hline Comments & $\begin{array}{l}\text { There should be further clarification regarding the issue of notification or } \\
\text { approval in the event of a credit institution acquiring less than } 5 \text { percent of } \\
\text { another institution. Less than } 5 \text { percent of another institution may still result in } \\
\text { as large risk to the acquiring institution and this needs to be evaluated. } \\
\text { In addition, it should be clarified that any combination of acquisitions of less } \\
\text { than } 5 \text { percent, which may result in a total acquisition position that results in a } \\
5 \text { percent or more position, needs the CBA's prior approval. }\end{array}$ \\
\hline Principle 6. & $\begin{array}{l}\text { Capital adequacy } \\
\text { Supervisors must set prudent and appropriate minimum capital adequacy } \\
\text { requirements for banks that reflect the risks that banks undertake, and must } \\
\text { define the components of capital, bearing in mind its ability to absorb losses. } \\
\text { At least for internationally active banks, these requirements must not be less } \\
\text { than those established in the applicable Basel requirement. }\end{array}$ \\
\hline Description & $\begin{array}{l}\text { Essential criteria: } \\
\text { 1. Section } 13 \text { (1) of the SOSCS grants CBA the authority to issue directives } \\
\text { regarding solvency, to include: } \\
\text { - the minimum amount of own funds which must be held in proportion to } \\
\text { risk-weighted loans, investments, other assets, off-balance sheet } \\
\text { engagements, interest, foreign and other market risks, holdings in other } \\
\text { enterprises and individual items } \\
\text { prohibition on, restricting of or the imposing of stipulations on loans, } \\
\text { investments, other assets, off-balance sheet engagements, }\end{array}$ \\
\hline & $\begin{array}{l}\text { Based on this directive, CBA sets the minimum risk weighted capital ratio for } \\
\text { commercial banks at } 12 \text { percent (since January } 1,2007) \text {. Offshore banks are } \\
\text { required to maintain a minimum risk weighted capital ratio of } 8 \text { percent. (In this } \\
\text { case it is just for Citibank. Any new offshore banks will be required to have a } \\
12 \text { percent capital ratio.) Capital adequacy ratios are calculated on both a } \\
\text { consolidated and a solo basis. Per Ministerial Decree, the minimum required } \\
\text { capital is AFL } 5 \text { million (approx. US } \$ 3 \text { million). }\end{array}$ \\
\hline & $\begin{array}{l}\text { 2. The definition of capital is consistent with the Basel I Capital Accord. } \\
\text { The required capital ratios are calculated for each bank and include risk } \\
\text { weighting for assets and off balance sheet items. The components of capital are } \\
\text { set forth in Appendix } 7 \text {, which is submitted by banks to CBA on a monthly } \\
\text { basis. The calculations are made on a consolidated basis. The year-end monthly } \\
\text { statement must be certified by an external auditor. }\end{array}$ \\
\hline & $\begin{array}{l}\text { Branches or subsidiaries of international banks that fall under consolidated } \\
\text { supervision are allowed to maintain a minimum risk-weighted assets ratio of } \\
8 \text { percent. }\end{array}$ \\
\hline
\end{tabular}




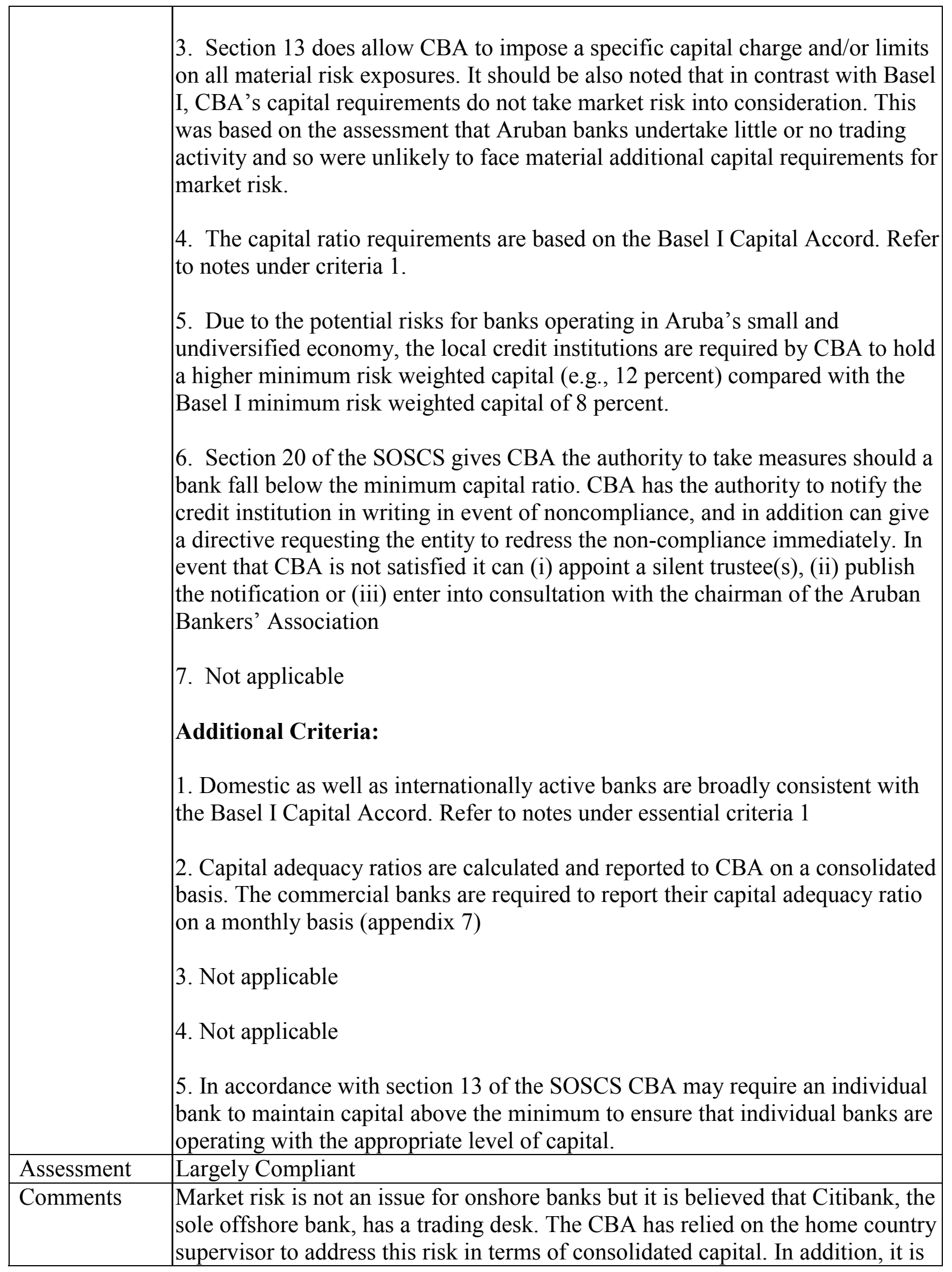




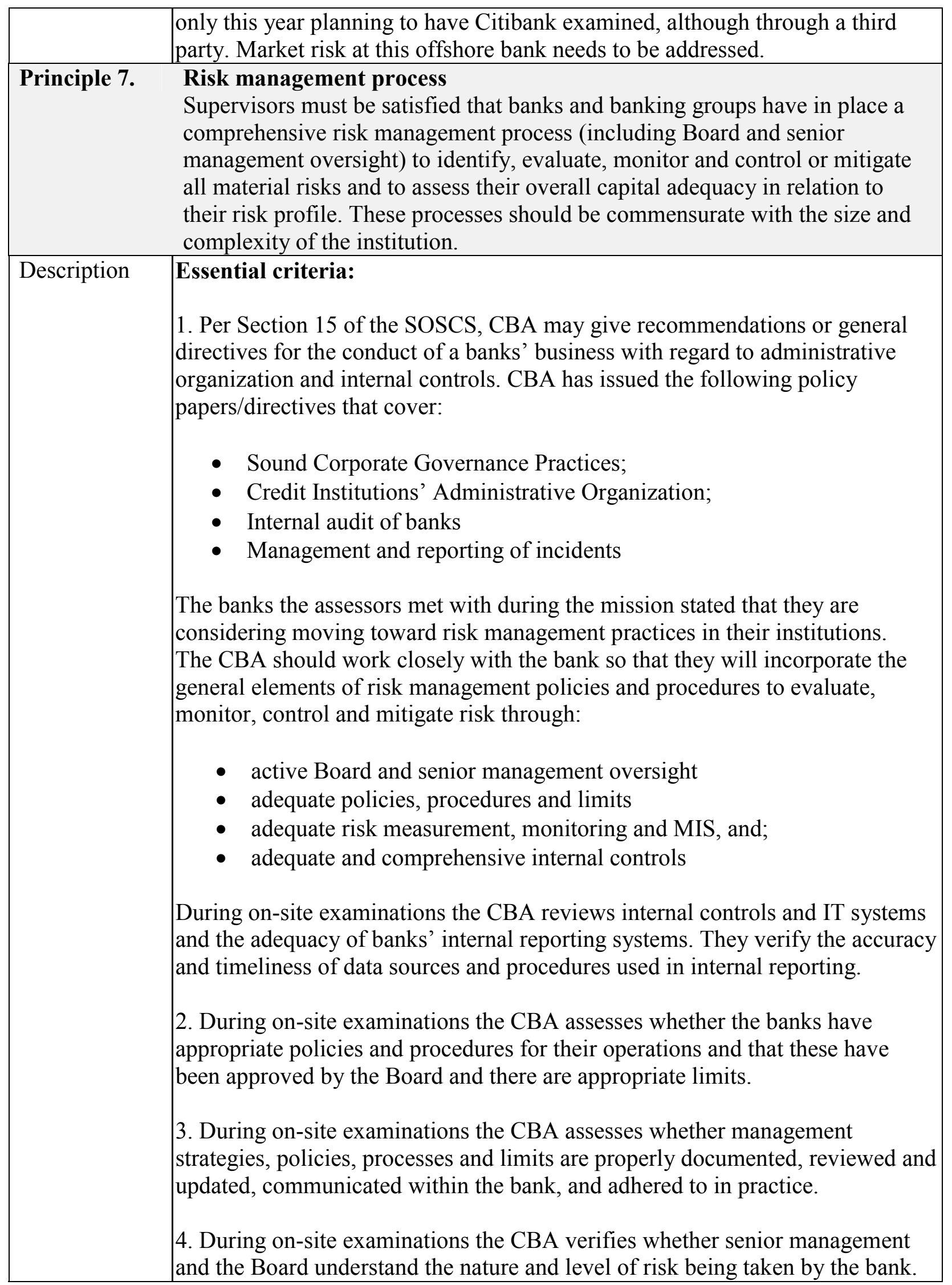




\begin{tabular}{|c|c|}
\hline & $\begin{array}{l}\text { Capital levels are set by the CBA for all banks. } \\
\text { 5. Not applicable. } \\
\text { 6. Not applicable } \\
\text { 7. According to CBA's policy paper on sound corporate governance practices } \\
\text { the risk management monitoring activities of credit institution's must be } \\
\text { supported by information systems that provide senior-management and Board } \\
\text { with timely reports on the financial condition, operating performance and risk } \\
\text { exposures of the financial institution. During on site examinations, the } \\
\text { adequacy of the information system is tested. } \\
\text { 8. During on-site examinations the CBA assesses whether banks have policies } \\
\text { and processes in place to ensure that new products are duly evaluated and } \\
\text { approved by the Board. } \\
\text { 9. According to the policy paper on credit institutions' administrative } \\
\text { organization the bank should have clear segregation of duties, which is tested } \\
\text { during on-site examinations. } \\
\text { 10. CBA has issued specific directives related to credit risk, country risk, } \\
\text { interest rate risk, and foreign exchange risk. Recently, CBA has also issued to } \\
\text { all credit institutions the Basel Committee papers on liquidity risk management } \\
\text { and supervisory challenges. } \\
\text { Additional criteria: } \\
\text { 1. CBA does not require banks to conduct stress testing. } \\
\text { 3. Not applicable }\end{array}$ \\
\hline Assessment & Materially Non Compliant \\
\hline Comments & $\begin{array}{l}\text { The CBA needs to enhance its ability to conduct risk based supervision and it } \\
\text { must work closely with the banks so that they incorporate risk management into } \\
\text { the way they run their operations. Supervision continues to be largely } \\
\text { compliance based in virtually all aspects. While risk based supervision includes } \\
\text { compliance, it should not be limited to it. Banks in Aruba do not have strategies } \\
\text { so much as forecast budgets. The supervisor could conduct training and } \\
\text { disseminate materials to the banks to make them more aware of risk } \\
\text { management. For supervisors and banks alike, it is a process of learning and } \\
\text { experience to make the move toward a risk based approach and it may take } \\
\text { time. }\end{array}$ \\
\hline Principle 8. & $\begin{array}{l}\text { must be satisfied that banks have a credit risk management } \\
\text { takes into account the risk profile of the institution, with prudent } \\
\text { processes to identify, measure, monitor and control credit risk }\end{array}$ \\
\hline
\end{tabular}


(including counterparty risk). This would include the granting of loans and making of investments, the evaluation of the quality of such loans and investments, and the ongoing management of the loan and investment portfolios.

\section{Description}

\section{Essential criteria:}

1. The legal authority for assessing credit risk management policies, practices and procedures is derived from section 15 of the SOSCS. In accordance with the terms of this section, CBA has issued a policy paper on Credit Risk Management, which sets forth in general terms for effective credit risk management. The purpose of credit risk management is to maintain credit risk exposure within acceptable parameters.

The policy paper provides guidelines on the following four areas of credit risk management:

- Credit risk environment

- Credit granting process

- Credit administration, measurement and monitoring process

- Controls over credit management

CBA conducts periodic on-site examinations where adherence by a bank to its credit risk policies, practices and procedures are reviewed.

2. CBA seeks to ensure that banks under its supervision have satisfactory policies and practices in place regarding the credit granting process. During these examinations the CBA conducts an appraisal of each bank's policy framework, its loan approval and administration procedures, assessment of processes governing analysis of borrowers, identifying problem assets, prudent lending controls and limits, and internal credit risk exposure grading systems.

On a more limited basis, external auditors are expected to notify CBA of material deficiencies in credit risk management policy or practice. However, assessments of policies and practices in these areas are not the primary function of the auditors' work.

The on-site examinations are supplemented with meetings with senior management of each bank. At these meetings, weaknesses identified from the on-site examinations or from the results of either internal or external audits are discussed.

3. The CBA's directive on credit risk management stipulates that all extensions of credit are made at arm's length, especially credits to related companies and individuals.

4. The CBA has full access to banks' information and records with respect to 


\begin{tabular}{|c|c|}
\hline & $\begin{array}{l}\text { the credit and investment portfolios and to the bank officers involved in } \\
\text { assuming, managing, controlling and reporting on credit risk. } \\
\text { Additional criteria: } \\
\text { 1. By virtue of section } 12 \text { of the SOSCS CBA has issued a directive on large } \\
\text { exposures to a group of connected clients requires, whereby major credit risk } \\
\text { exposures exceeding a certain percentage of the bank's capital are to be decided } \\
\text { by the bank's senior management. } \\
\text { 2. The directive on credit risk management stipulates that a credit institution } \\
\text { should establish a system of credit risk management policy and processes to } \\
\text { identify, measure, monitor and control counterparty credit risk. Compliance is } \\
\text { tested during on-site examinations. } \\
\text { 3. The directive on credit risk management stipulates that a credit institution } \\
\text { should have policies and processes in place to monitor indebtedness of entities } \\
\text { to which credit has been extended. Compliance is tested during on-site } \\
\text { examinations. }\end{array}$ \\
\hline Assessment & Largely Compliant \\
\hline Comments & $\begin{array}{l}\text { Aruba has a relatively small population (approximately 100,000) and tourism is } \\
\text { the dominant industry. Lending by banks in Aruba is largely concentrated in } \\
\text { secured personal loans, real estate mortgages, and some commercial lending for } \\
\text { small local businesses, which is largely secured. For the most part, the loan } \\
\text { portfolio could be considered retail. As such, the approach to credit risk } \\
\text { management is generally appropriate. Supervision as well as credit risk } \\
\text { management in banks would be enhanced by a refinement in presentation of } \\
\text { data as a start. Right now, inspection reports include client by client lists of } \\
\text { borrowers, amounts outstanding, past due status and provisioning. This } \\
\text { information should be presented and analyzed in a more risk based approach } \\
\text { that allows for trends, improvements and changes by category of borrower, by } \\
\text { size of loan, etc. This will also enable the CBA to perform more meaningful } \\
\text { financial analysis of banks' financial results. }\end{array}$ \\
\hline e 9. & $\begin{array}{l}\text { Problem assets, provisions and reserves } \\
\text { Supervisors must be satisfied that banks establish and adhere to adequate } \\
\text { policies and processes for managing problem assets and evaluating the } \\
\text { adequacy of provisions and reserves. }\end{array}$ \\
\hline Description & $\begin{array}{l}\text { Essential criteria } \\
\text { 1. In accordance with section } 13 \text { (1) of the SOSCS CBA has issued a directive } \\
\text { on loan loss provisioning requiring banks to maintain adequate provision for } \\
\text { depreciation or diminution in the value of assets. The objective is to provide the } \\
\text { credit institutions with guidelines for the establishment of effective policies and } \\
\text { criteria for loan loss classification and provisioning. It deals with both the } \\
\text { general (unallocated) and allocated loan loss provisions. }\end{array}$ \\
\hline
\end{tabular}


In general, loans with past due status larger than 90 days on the payment of interest and or principal are considered to be non-performing. Non-performing loans are divided into three categories:

- Loans with a past due status between 91-180 days

- Loans with a past due status between 181 days and one year

- Loans with a past due status of more than one year.

Banks are also required to maintain an unallocated loan loss provision, which should be considered as a special form of a dynamic provision related to the general risk a credit institution runs, directly or indirectly, originating from granting loans and conducting other banking activities. This provision serves as a buffer for possible losses. Each bank is required to maintain a general provision of at least 3 percent of the net loan portfolio plus other risk items on the asset side of the balance sheet.

2. CBA supplements its monitoring program with its cyclical on-site credit risk management review program. CBA examiners review a sample of credits for adherence to credit policy and for completeness of credit files with respect to the credit approval process, bank generated credit analysis, and evidence that collateral has been properly recorded. On-site examinations are conducted annually for the commercial banks.

The external auditors, when conducting the audit of the financial statements, review the provisioning policies of the banks and the actual level of provisions.

According to CBA's policy paper on credit risk credit institutions are required to monitor individual credits and determine the adequacy of provisions and reserves. This monitoring should include identification of delinquencies and classification of problem credits.

3. CBA's system of classification and provisioning also takes into account offbalance sheet exposures.

4. The CBA determines through on-site examinations that banks have appropriate policies and procedures in place to ensure that loan loss provisions and write-offs reflect realistic repayment expectations.

5. The CBA determines through on-site examinations that banks have appropriate procedures and organizational resources for the ongoing oversight of problem credits and for collecting past due loans.

6. The CBA collects information on non-performing and allocated loan loss provisions on a quarterly basis (appendices 12 and 13). Furthermore, during onsite examinations the CBA is informed in detail on the loan classification and the (un)allocated loan loss provisions. 


\begin{tabular}{|c|c|}
\hline $\begin{array}{l}\text { Assessment } \\
\text { Comments }\end{array}$ & 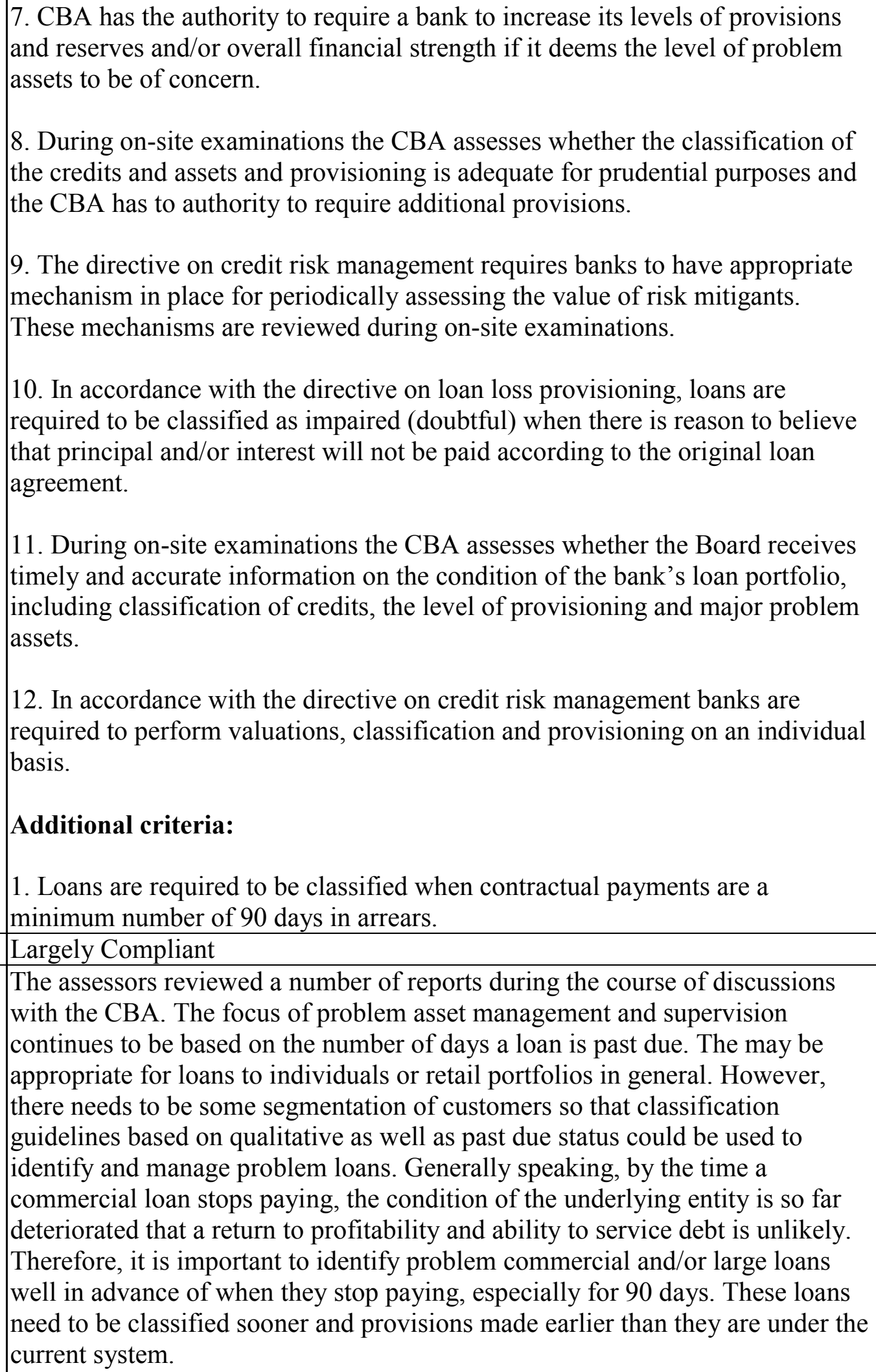 \\
\hline
\end{tabular}




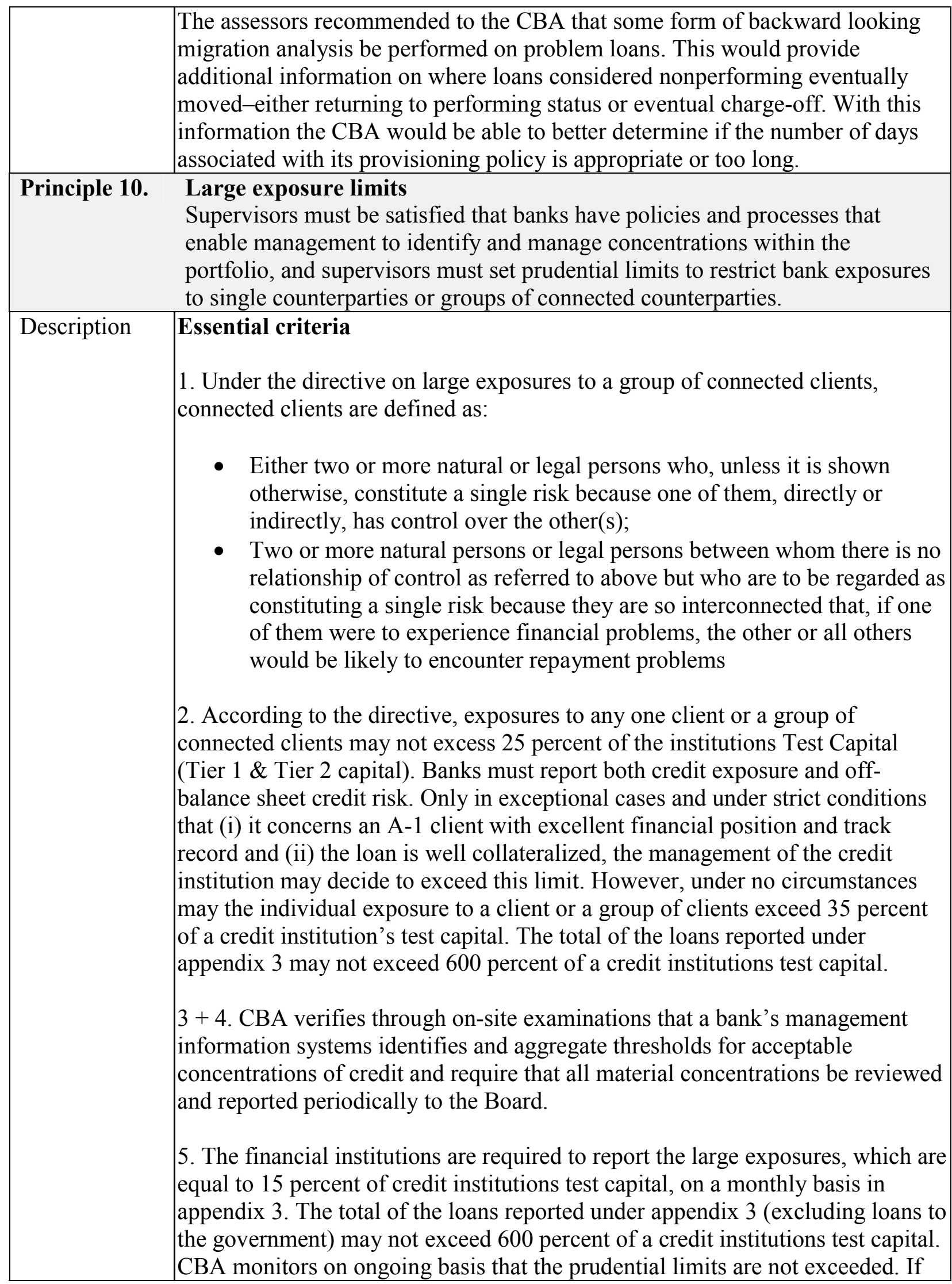




\begin{tabular}{|c|c|}
\hline & $\begin{array}{l}\text { CBA ascertains that a credit institution does not comply with said directive it } \\
\text { can take corrective measures to require said institution to comply. } \\
\text { Additional criteria: } \\
\begin{array}{l}\text { 1. Refer to notes under criteria } 10 \\
\text { limits if explicitly temporary. }\end{array}\end{array}$ \\
\hline Assessment & Compliant \\
\hline Comments & $\begin{array}{l}\text { Banks' credit risk management and the CBA's ability to supervise would be } \\
\text { enhanced by better reporting and analysis of large exposures. Appendix } 3 \text { is } \\
\text { now basically a list of large exposures. The banks should view their borrowers } \\
\text { by certain categories that would be appropriate in the Aruban context. These } \\
\text { could include by business type, by employer, industry, profession, by collateral } \\
\text { type, by size loan, etc. This may provide some additional information that } \\
\text { would improve knowledge on the part of the bankers regarding their portfolios } \\
\text { and enhance their credit risk management abilities. }\end{array}$ \\
\hline Prin & $\begin{array}{l}\text { Exposures to related parties } \\
\text { In order to prevent abuses arising from exposures (both on-balance sheet and } \\
\text { off-balance sheet) to related parties and to address conflict of interest, } \\
\text { supervisors must have in place requirements that banks extend exposures to } \\
\text { related companies and individuals on an arm's length basis; these exposures } \\
\text { are effectively monitored; appropriate steps are taken to control or mitigate } \\
\text { the risks; and write-offs of such exposures are made according to standard } \\
\text { policies and processes. }\end{array}$ \\
\hline Description & $\begin{array}{l}\text { Essential criteria: } \\
\text { 1. Under the supervisory directive on credit extensions to insiders issued } \\
\text { pursuant to section } 13 \text { of the SOSCS the aggregated amount of all credit } \\
\text { extensions to insiders or to companies in which insiders are majority } \\
\text { shareholders may not exceed } 2 \text { percent of the credit institutions regulatory } \\
\text { capital, or } 1 \text { percent thereof in case of any individual extension. Credit } \\
\text { extensions to insiders are defined to include loans, overdraft facilities and } \\
\text { guarantees. An insider is defined as any manager, director and/or shareholder } \\
\text { including partners or relatives in the first and second degree. ...... } \\
\text { 2. The directive requires that exposures to related parties not be on more } \\
\text { favorable terms than those granted to non-related borrowers under similar } \\
\text { circumstances. Compliance is tested during on-site examinations. } \\
\text { 3. Banks' policies and procedures are required to include the explicit } \\
\text { requirement that limits that are exceeded are approved by the bank's } \\
\text { management. This is confirmed during on site examinations through a review of } \\
\text { the Board minutes. Board members with conflict of interest are excluded from } \\
\text { the approval process. }\end{array}$ \\
\hline
\end{tabular}




\begin{tabular}{|c|c|}
\hline & $\begin{array}{l}\text { 4. According to the directive, banks are required to establish a written } \\
\text { comprehensive policy with regard to credit extension to insiders. Bank's } \\
\text { policies and procedures are also required to prevent persons who benefit from } \\
\text { loans from being part of the loan evaluation and decision process. Compliance } \\
\text { is tested during on-site examinations. } \\
\text { 5. The aggregate amount of all credit extensions to insiders may not exceed } 2 \\
\text { percent of the institution's capital base, or } 1 \text { percent thereof in case of any } \\
\text { individual credit extension. According to the directive CBA reserves the right to } \\
\text { deduct the amount in excess of the } 2 \text { percent limit from the credit institution's } \\
\text { test capital. } \\
\text { 6. Refer to notes under criteria CP } 11 \text { (4). } \\
\text { 7. Banks are required to report on aggregate exposures to related parties. }\end{array}$ \\
\hline Assessment & Largely Compliant \\
\hline Comments & $\begin{array}{l}\text { Insiders are generally a sub-set of the related parties. Companies where insiders } \\
\text { have a significant interest (even if it does not constitute a majority share) could } \\
\text { be considered related to the bank. Terms and conditions of loans granted to } \\
\text { these companies should not be granted on more favorable terms than } \\
\text { corresponding exposures to non-related parties. }\end{array}$ \\
\hline Pri & $\begin{array}{l}\text { Country and transfer risks } \\
\text { Supervisors must be satisfied that banks have adequate policies and processes } \\
\text { for identifying, measuring, monitoring and controlling country risk and } \\
\text { transfer risk in their international lending and investment activities, and for } \\
\text { maintaining adequate provisions and reserves against such risks. }\end{array}$ \\
\hline Description & $\begin{array}{l}\text { Essential criteria } \\
\text { 1. Under the policy paper on country risk management issued pursuant to } \\
\text { section } 15 \text { of the SOSCS each credit institution should monitor on an on-going } \\
\text { basis its country risk exposure and establish an adequate country risk } \\
\text { management policy. The country risk exposure should be reported under } \\
\text { appendix } 14 \text { to CBA once a year together with the statement of December. Any } \\
\text { loan, investment and/or off-balance sheet item to a foreign country should be } \\
\text { disclosed. } \\
\text { Furthermore, the guidance paper on Foreign Exchange Risk Management } \\
\text { pursuant section } 13 \text { of the SOSCS provides credit institutions guidelines to } \\
\text { establish an adequate foreign risk management policy that effectively identifies, } \\
\text { measure, monitors and controls foreign exchange risk exposures which is } \\
\text { subject to appropriate board and senior management oversight. Appendix } 16 \\
\text { requires banks to report once a year (statement of December) their foreign } \\
\text { exchange risk exposure. }\end{array}$ \\
\hline
\end{tabular}




\begin{tabular}{|c|c|}
\hline & $\begin{array}{l}\text { It should be noted that the onshore banks have low levels of country and foreign } \\
\text { exchange risks. Most country risk exposure is to the Netherlands Antilles. } \\
\text { Therefore, country and transfer risks are considered minimal. The required } \\
\text { solvency ratio of } 12 \text { percent is considered sufficient to cover these risks. } \\
\text { Country and transfer risks exist in the offshore banks. Country risk provisioning } \\
\text { is at head office level for the offshore banks and the CBA depends on the parent } \\
\text { bank and the home country supervisor to address country risk issues and share } \\
\text { this information with the Bank. } \\
\text { 2. Banks policies and procedures for addressing country and foreign exchange } \\
\text { risks are reviewed during onsite examinations in the course of review of loan } \\
\text { and investment portfolios and internal controls. The required solvency ratio of } \\
\text { 12 percent for onshore banks is meant to cover country risk and transfer risk as } \\
\text { more than } 90 \text { percent of loan portfolios are domestic. } \\
\text { 3. The CBA considers country and transfer risks to be minimal. The required } \\
\text { solvency ratio of } 12 \text { percent is meant to cover these risks. } \\
\text { 4. Refer to notes } 11 \text { (1). Also, during on-site examinations these risks are } \\
\text { assessed as part of the review of the loan- and investment portfolio. }\end{array}$ \\
\hline Assessment & Largely Compliant \\
\hline Comments & $\begin{array}{l}\text { Even though the CBA considers these risks to be minimal it should receive } \\
\text { reports on these positions with more frequency than once a year. At } 10 \text { percent } \\
\text { of total loans in foreign exchange it is not minimal. If banks change their } \\
\text { positions they could be taking on additional risks and the supervisor should be } \\
\text { aware at all times. At least quarterly reporting should be required. }\end{array}$ \\
\hline Prin & $\begin{array}{l}\text { Market risk } \\
\text { Supervisors must be satisfied that banks have in place policies and processes } \\
\text { that accurately identify, measure, monitor and control market risks; } \\
\text { supervisors should have powers to impose specific limits and/or a specific } \\
\text { capital charge on market risk exposures, if warranted. }\end{array}$ \\
\hline Description & $\begin{array}{l}\text { Essential criteria: } \\
\text { 1. There are no specific capital charges for market risk and foreign exchange } \\
\text { risk given the very limited participation of onshore banks in this activity since } \\
\text { they undertake very little or no trading activity. Foreign exchange positions are } \\
\text { limited to the U.S. dollar and the Netherlands Antilles guilder. Both the Aruban } \\
\text { florin and the Antilles guilder are pegged to the dollar and have been stable. } \\
\text { CBA acknowledges that the offshore banks are prone to market risk. Note also } \\
\text { that CBA is in the process of outsourcing the onsite examinations on the } \\
\text { offshore entities.. } \\
\text { 2. The CBA does not set market risk limits. }\end{array}$ \\
\hline
\end{tabular}




\begin{tabular}{|c|c|}
\hline & $\begin{array}{l}\text { 3. The CBA does not examine for market risk. It is in the process of arranging } \\
\text { for an external audit firm to conduct an examination of the offshore banks. } \\
\text { Market risk should be included in the terms of reference. } \\
\text { 4. The CBA does not require stress testing, scenario analysis or contingency } \\
\text { planning with regard to market risk. } \\
\text { Additional criteria: } \\
\text { 1. The local credit institutions have only limited exposure to market risk, since } \\
\text { they undertake very little trading activity. }\end{array}$ \\
\hline Assessment & Non Compliant \\
\hline Comments & $\begin{array}{l}\text { While these risks may be covered by the } 12 \text { percent capital charge for the } \\
\text { onshore banks, there is a need to address market risk in the offshore banks. } \\
\text { The CBA is in the process of arranging for an external audit firm to conduct an } \\
\text { examination of the offshore banks. Market risk should be included in the terms } \\
\text { of reference. }\end{array}$ \\
\hline Principle 14. & $\begin{array}{l}\text { Liquidity risk } \\
\text { Supervisors must be satisfied that banks have a liquidity management strategy } \\
\text { that takes into account the risk profile of the institution, with prudent policies } \\
\text { and processes to identify, measure, monitor and control liquidity risk, and to } \\
\text { manage liquidity on a day to day basis. Supervisors require banks to have } \\
\text { contingency plans for handling liquidity problems. }\end{array}$ \\
\hline Description & $\begin{array}{l}\text { Essential criteria } \\
\text { The CBA has issued specific liquidity guidelines based on Section } 14 \text { of the } \\
\text { SOSCS, which sets a prudential liquidity ratio, defined as liquid assets divided } \\
\text { by total assets, at a minimum of } 20 \text { percent. In addition, the commercial banks } \\
\text { have to comply with a maximum loan-to-deposit ratio of } 80 \text { percent. } \\
\text { Concentration of deposits is addressed with an extra liquidity requirement } \\
\text { of } 20 \text { percent of all deposits larger than } 1 \text { percent of total liabilities. The actual } \\
\text { ratios are reported to the Bank on a monthly basis. } \\
\text { Credit institutions are also required to submit a liquidity testing sheet on a } \\
\text { monthly designed to assess the liquidity in the resident and non-resident sector } \\
\text { separately. A specific liquidity charge is attached to the eligible balance sheet } \\
\text { and off-balance sheet items. At the moment these are the most important } \\
\text { liquidity tools that the commercial banks have to comply with. } \\
\text { CBA has recently issued to all credit institutions a copy of the Basel's } \\
\text { Committee papers on Liquidity risk: management and Supervisory Challenges } \\
\text { and the guidance paper: Sound practices for managing liquidity risk in banking } \\
\text { organizations. }\end{array}$ \\
\hline
\end{tabular}




\begin{tabular}{|c|c|}
\hline & $\begin{array}{l}\text { Additional criteria: } \\
\text { 1. The local banks do not conduct business in multiple currencies. The offshore } \\
\text { bank conducts its business in multiple currencies } \\
\text { 2. This type of review is not conducted. }\end{array}$ \\
\hline Assessment & Largely Compliant \\
\hline Comments & $\begin{array}{l}\text { The liquidity ratios and liquidity reporting requirements are in proportion to the } \\
\text { liquidity risks in the Aruban banking sector. The required ratios serve to } \\
\text { maintain reasonable levels of liquidity given the operations of the local banks. } \\
\text { The CBA needs to be more proactive in overseeing liquidity risk management } \\
\text { in banks. Having the banks report liquidity ratios is a first step, but more } \\
\text { proactive liquidity risk management guidance is needed by the industry. } \\
\text { The CBA needs to ensure that banks have acceptable liquidity management } \\
\text { strategies and policies and procedures for managing the risks, including } \\
\text { ongoing management of funding requirements. Senior management and Board } \\
\text { oversight are critical. The CBA also needs to ensure that banks have liquidity } \\
\text { contingency plans and that these are periodically confirmed for availability. }\end{array}$ \\
\hline Principle 15. & $\begin{array}{l}\text { Operational risk } \\
\text { Supervisors must be satisfied that banks have in place risk management } \\
\text { policies and processes to identify, assess, monitor and control/mitigate } \\
\text { operational risk. These policies and processes should be commensurate with } \\
\text { the size and complexity of banks. }\end{array}$ \\
\hline Description & $\begin{array}{l}\text { Essential criteria: } \\
\text { 1. CBA requires banks to monitor operational risk in accordance with its Policy } \\
\text { Paper on Sound corporate governance practices. The policy paper notes } \\
\text { elements of sound corporate governance practices including establishing } \\
\text { strategic objectives and corporate values, setting and enforcing clear lines of } \\
\text { responsibility and accountability, ensuring that board members and senior- } \\
\text { management are qualified, adequate risk management, internal controls, and } \\
\text { financial disclosure. Adherence to supervisory and internal guidelines is tested } \\
\text { during on site examinations. Under the corporate governance practices } \\
\text { individual banks are required to implement risk management policies and } \\
\text { procedures to identify, assess, monitor and mitigate risks posed by its activities, } \\
\text { which should include operational risks. } \\
\text { 2. The Supervisory Board should ensure that proper risk management risk } \\
\text { strategies and procedures are approved and implemented by senior-management } \\
\text { and ensure compliance. Adherence is tested by CBA during on-site } \\
\text { examinations. }\end{array}$ \\
\hline
\end{tabular}




\begin{tabular}{|c|c|}
\hline & $\begin{array}{l}\text { 3. CBA reviews during on-site examinations whether the approved strategy and } \\
\text { significant policies and processes for operational risk are implemented } \\
\text { effectively by management. } \\
\text { 4. CBA reviews during on-site examinations the quality of the bank's business } \\
\text { contingency plans and information technology policies and processes that } \\
\text { address areas such as information security and system development. Review of } \\
\text { the general computer controls are also part of the regular on-site examinations } \\
\text { at credit institutions. } \\
\text { 5. This area is not covered explicitly by CBA during its regular on-site } \\
\text { examination program, but partially through an IT review (GCC). } \\
\text { 6. According to directive on the management and reporting of incidents issued } \\
\text { pursuant section } 15 \text { of the SOSCS banks are required to adopt a policy } \\
\text { regarding the management and reporting of operations risk related incidents. } \\
\text { This policy requires administrative recording and reporting of incidents, method } \\
\text { of incident handling to be used, and reporting of information on incidents. A } \\
\text { bank is required to notify CBA without delay of incidents. } \\
\text { 7. According CBA's sound practice on corporate governance banks are required } \\
\text { to incorporate legal risk into their operational risk management processes. } \\
\text { During on-site examinations adherence is reviewed by CBA. } \\
\text { 8. CBA does not yet have explicit guidelines covering the outsourcing of } \\
\text { activities. It intends to issue said guidelines in the course of this year. } \\
\text { hdditional criteria: } \\
\text { have not yet had oversight in this area. }\end{array}$ \\
\hline Asse & Largely compliant \\
\hline Comments & $\begin{array}{l}\text { There is room for improvement in the area of risk management at the banks and } \\
\text { its oversight by the CBA. During on-site examinations various elements that } \\
\text { constitute operational risk areas are looked at. However, they need to be } \\
\text { evaluated in greater depth and the CBA needs to provide additional guidance to } \\
\text { banks in this area. It is a relatively new area of risk for banks and supervisors to } \\
\text { address and the CBA should continue to allocate further resources to this area. } \\
\text { The CBA should work closely with the banks to ensure that they develop and/or } \\
\text { improve their capacity to identify, assess, monitor and mitigate operational risk } \\
\text { events in a manner that is commensurate with the size and complexity of their } \\
\text { operations. }\end{array}$ \\
\hline & Interest rat \\
\hline
\end{tabular}




\begin{tabular}{|c|c|}
\hline & $\begin{array}{l}\text { identify, measure, monitor and control interest rate risk in banking book, } \\
\text { including a well defined strategy that has been approved by the Board and } \\
\text { implemented by senior management; these should be appropriate to the size } \\
\text { and complexity of such risk. }\end{array}$ \\
\hline Description & $\begin{array}{l}\text { Essential criteria: } \\
\text { CBA has issued a guidance paper on interest rate risk management pursuant to } \\
\text { section } 13 \text { of the SOSCS. The purpose of the guidance paper is to provide banks } \\
\text { with guidelines to establish an adequate interest risk management policy that } \\
\text { effectively identifies, measures, monitors and controls interest rate risk } \\
\text { exposures and that is subject to appropriate board and senior management } \\
\text { oversight. } \\
\text { Banks are required to report on an annual basis the interest risk exposure based } \\
\text { on the gap analysis (appendix 15). This report is intended to collect information } \\
\text { on banks interest rate risk exposure, ensuing from repricing risk, which } \\
\text { constitutes the primary source of interest rate risk in Aruba, according to the } \\
\text { CBA. } \\
\text { The onshore banks are not yet required to periodically perform stress tests to } \\
\text { measure their vulnerability under adverse interest rate movement. } \\
\text { Additional criteria: } \\
\text { The CBA does not require any elements of the additional criteria of banks. }\end{array}$ \\
\hline Assessment & Materially Non Compliant \\
\hline Comments & $\begin{array}{l}\text { The CBA needs to be more proactive in its supervision of interest rate risk } \\
\text { management in banks. Banks should have in place a comprehensive policy on } \\
\text { interest rate risk management comprising of four basic elements: appropriate } \\
\text { board and senior management oversight, adequate risk management policies } \\
\text { and procedures, appropriate risk measurement and monitoring systems and } \\
\text { comprehensive internal controls and independent external audits. } \\
\text { It is the CBA's assertion that the interest margin at the domestic commercial } \\
\text { banks is high and that adverse movements in the interest rate can be absorbed } \\
\text { by them. This may be a good risk mitigant to the losses that could result from } \\
\text { poor interest risk management practices. However, the current reporting the } \\
\text { CBA requires of banks does not adequately capture the information needed to } \\
\text { assess interest rate risk in banks. Therefore, it is not as useful a tool as it could } \\
\text { be, for the banks or the CBA. Shorter repricing periods than are currently } \\
\text { reported would allow for analysis of interest rate repricing gaps' impact on } \\
\text { earnings. In addition, banks are only required to provide the report once a year } \\
\text { which is too infrequent to be a meaningful risk management tool and to provide } \\
\text { adequate disclosure as to periodic interest rate risk positions. }\end{array}$ \\
\hline
\end{tabular}




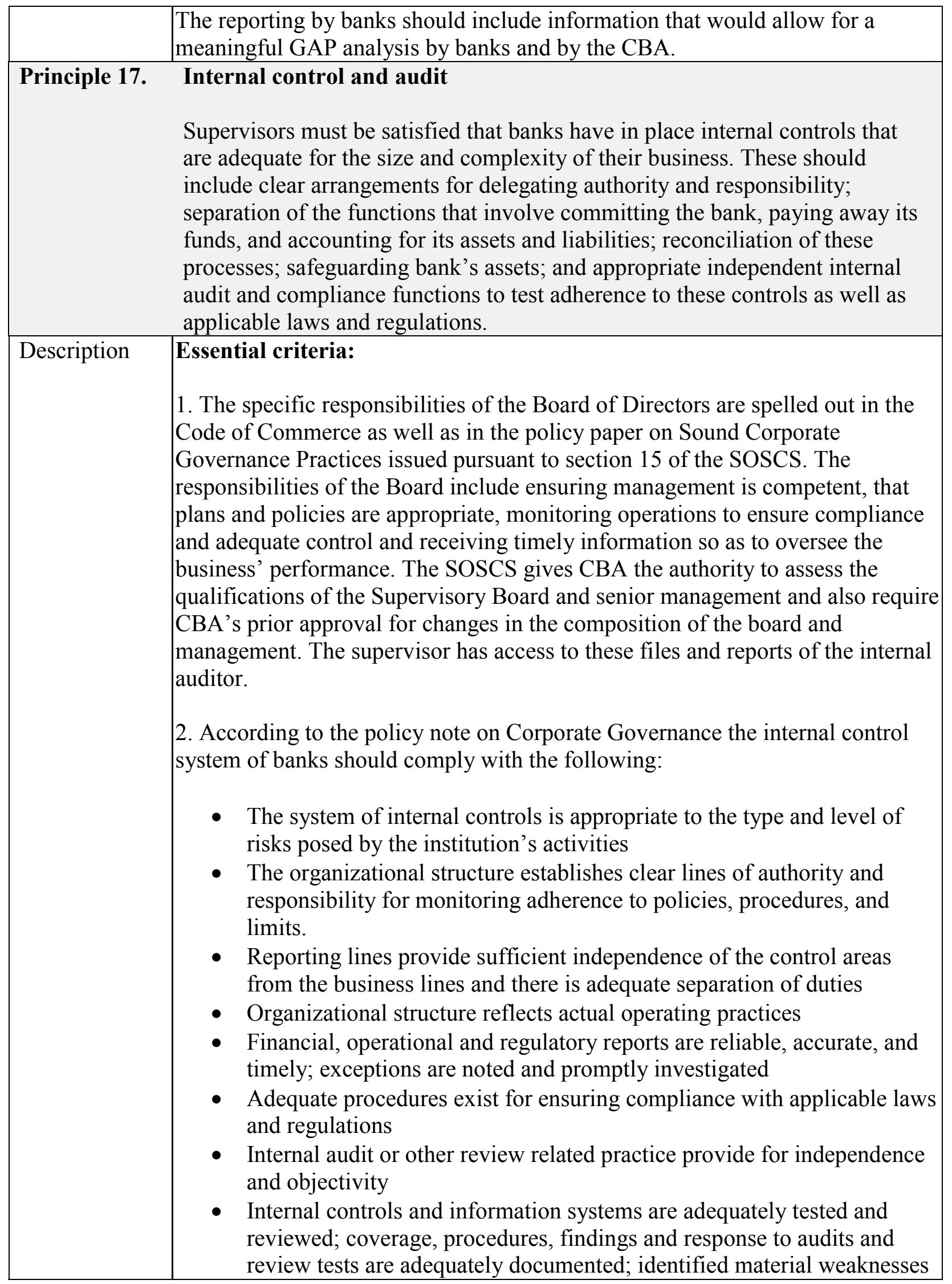


are given appropriate and timely attention.

- The Board, in consultation with senior management, annually reviews the effectiveness of internal audits and other review activities.

CBA has also issued by virtue of section 15 of the SOSCS a directive on internal audit in banks. This directive discusses principles that banks should follow when designing and implementing internal audit. These principles addresses objectives and tasks of the internal audit function, principles of internal audit, and functioning of internal audit.

CBA reviews internal audit systems as part of the on-site examination program. In the course of these reviews, CBA examiners test the efficacy with which they are performed and adherence to policy and procedure. In addition, external auditors, in connection with their annual audit and certification of a bank's financial statements, reach an opinion on whether the internal control system is adequate for the nature and scale of bank's business. Management letters are issued by the external auditors describing weaknesses that must be corrected. CBA also receives and reviews the management letters.

3. In accordance with CBA's policy on sound corporate governance practices the Board and senior management are responsible for the control environment. The Board as a whole is responsible for monitoring operations to ensure compliance and adequate control and the senior management is responsible for implementing adequate and comprehensive internal controls. This is reviewed during on-site examinations.

4. The SOSCS gives the CBA the authority to assess the qualifications of the Board and senior management and to require approval of CBA for changes in the composition of the Board and management. However, the CBA does not have the authority to require changes of the Board or senior management.

5. During on-site examinations the CBA determines that there is an appropriate balance in the skills and resources of back office relative to front office.

6. Internal audit is viewed as a valuable part of the compliance function of banks. In addition, CBA requires all commercial banks to have a permanent compliance officer that assist senior management in managing effectively the compliance risks faced, amongst other in the area of AML/CFT. The compliance function is reviewed during on-site examinations, which involves assessing the Board oversight of the management of the compliance function.

7. In accordance with the directive on internal audit in banks CBA requires that internal controls within banking organizations must be supplemented by an effective internal audit function that independently evaluates the control systems within the banking organization. CBA during the course of on-site examinations reviews the adequacy and effectiveness of the internal audit 


\begin{tabular}{|c|c|}
\hline & $\begin{array}{l}\text { function, including unfettered access to bank information and independence. } \\
\text { Also, internal audit reports are reviewed and commented. } \\
\text { 8. CBA, during the course of on-site examinations, reviews the adequacy and } \\
\text { efficiency of the internal audit function, including unfettered access to banks } \\
\text { information and independence and reporting lines. CBA seeks to ensure that } \\
\text { issues raised by internal auditors are resolved by the management. } \\
\text { The supervisory review process includes meetings with internal auditors, } \\
\text { management, external auditors, review of audit plans and reports. } \\
\text { Additional criteria: } \\
\text { 1. Not applicable. } \\
\text { 2. Not applicable. } \\
\text { 3. Not applicable. } \\
\text { 4. According the Directive on management and reporting of incidents banks } \\
\text { must notify the CBA of any material information which may negatively affect } \\
\text { the fitness and property of Board members or a member of senior management. }\end{array}$ \\
\hline Assessment & Compliant \\
\hline Comments & \\
\hline Principle 18. & $\begin{array}{l}\text { Abuse of financial services } \\
\text { Supervisors must be satisfied that banks have adequate policies and processes } \\
\text { in place, including strict "know-your-customer" rules, that promote high } \\
\text { ethical and professional standards in the financial sector and prevent banks } \\
\text { from being used, intentionally or unintentionally, for criminal activities. }\end{array}$ \\
\hline Description & $\begin{array}{l}\text { Essential criteria: } \\
\text { 1. CBA and the Reporting Center Unusual Transactions (RCUT) are entrusted } \\
\text { with the execution of the State Ordinance on the Identification for rendering } \\
\text { Financial Services (SOIRFS). The SOIFRS requires service providers who } \\
\text { render financial services to obtain and record the necessary customer due } \\
\text { diligence before entering into a relationship or conducting certain transactions } \\
\text { with the person. CBA is entrusted with overseeing compliance with the } \\
\text { stipulations of the SORUT, insofar as it concerns the financial institutions } \\
\text { under its supervision. In December } 2005 \text { a Memorandum of Understanding } \\
\text { was signed between CBA and the RCUT on the exchange of general } \\
\text { information on money laundering and terrorist financing issues. } \\
\text { Primarily based on the Customer Due Diligence guidelines issued by the Basel } \\
\text { Committee on Banking Supervision, CBA issued in December } 2005 \text { a directive } \\
\text { for banks on Customer Due Diligence. This directive was issued pursuant to } \\
\text { section } 15 \text { of the SOSCS, and contains minimum standards in the areas of } \\
\text { customer acceptance policy, customer identification, on-going monitoring of }\end{array}$ \\
\hline
\end{tabular}


accounts and transactions, and risk management. The directive became effective January 1, 2006.

2. CBA examines for compliance during on site examinations. It has performed targeted anti money laundering examinations apart from its regular schedule of full scope on site examinations, which are conducted annually. CBA reviews compliance with know-your-customer guidelines and the adequacy of processes and procedures to report suspicious transactions. It checks the adequacy of processes and procedures by reviewing organizational and/or procedural changes, it reviews the findings of the compliance officer, reviews follow up to information requests from the Court of Justice and it analyzes the list of accounts closed since the previous examination. Offshore banks have not had anti money laundering inspections although they are required to report suspicious transactions.

The RCUT also conducts on-site inspection at the onshore banks. The RCUT inspections focuses on compliance with the reporting requirements and have also included assessments of the adequacy of policies, staffing, compliance with the law, and spot checks on the completed transactions by analyzing specific accounts. RCUT coordinates its inspections with CBA. When deficiencies are found, RCUT advises banks on how to correct them. Both CBA and RCUT have the legal authority to ensure enforcement of the supervisory requirements for anti money laundering.

3. In addition to reporting to the RCUT, banks are required to report suspicious activities and material frauds to CBA. This is based on the directive on the management and reporting of incidents.

4. Banks are required to have effective KYC procedures in place which are well documented and communicated to all relevant staff. KYC should be a core feature of banks' risk management and control procedures, and complemented by regular compliance reviews and internal audit. In this respect, the banks' internal audit and compliance function must have important responsibilities in evaluating and ensuring adherence to KYC policies and procedures. Key elements which should be included in the design of KYC program are:

- customer acceptance policy,

- customer identification,

- on-going monitoring of high risk accounts, and

- risk management.

Banks should not only establish the identity of their customers, but should also monitor account activity to determine whether or not those transactions conform with the normal or expected transactions for that customer or type of account.

5. Banks are required to have enhanced due diligence policies and processes in 
place regarding correspondent banking. These policies and processes should encompass the gathering of information on correspondent banks (management, activities, location and $\mathrm{KYC}$ efforts) and refusal to correspond with banks in jurisdictions that have poor KYC standards or have been identified as being non-cooperative.

6. CBA conducts periodic AML/CFT onsite examinations to verify whether the banks have sufficient controls and systems in place for preventing, identifying and reporting abuses of financial services. CBA conducts testing of compliance through interviews with relevant staff and sample testing of client's files to ensure that policies are adhered to.

7. If CBA ascertains that an institution is not complying with relevant laws and/or regulations it can take corrective measures. Section 20 of the SOSCS gives CBA, for example, the authority, to notify the institution in writing or give directions on the course of action to be pursued. (See CP 23 - Remedial Measures)

8. CBA conducts periodic AML/CFT onsite examinations at banks to confirm that banks meet the requirements for internal audit to independently evaluate risk management policies, the compliance function, the screening policies and processes and ongoing training programs for staff. CBA conducts testing of compliance through interviews with the compliance officer and other relevant staff and reviewing of training programs.

9. CBA conducts periodic AML/CFT onsite examinations at banks to determine that banks have clear policies and processes for staff to report any problems related to the abuse of banks financial services to the compliance officer or management.

10. The compliance officer at banks is typically charged with the responsibility to ensure a bank's anti money laundering policies and procedures are in accordance with statutory and regulatory requirements. Suspicious transactions within a bank are reported to the compliance officer. Banks report suspicious transactions to the RCUT and can go directly to the Prosecutor's Office. Banks' staff members and the CBA itself, cannot be held liable for the reporting in good faith of suspicious transactions to the RCUT.

11. At present, CBA has no legal obligation to directly inform the financial intelligence unit of suspicious transactions. Note that banks are required to report any unusual transactions to the RCUT. CBA can also issue a binding instruction to this effect to the institution concerned.

12. In accordance with section 34 of the SOSCS CBA can share information with colleague supervisors. In this respect, CBA and the RCUT have signed a MOU on the sharing of information. Both entities meet at least twice a year to 


\begin{tabular}{|c|c|}
\hline & $\begin{array}{l}\text { share information on the development in the area of AML/CFT. Also, the CBA } \\
\text { is a member of the Aruban FATF commission, which coordinates all AML/CFT } \\
\text { efforts on a national level. } \\
\text { Additional Criteria: } \\
\text { 1. Not applicable }\end{array}$ \\
\hline Assessment & Compliant \\
\hline Comments & $\begin{array}{l}\text { While overall the approach and implementation in this CP is thorough, some } \\
\text { enhancements should be made. The offshore banks should be examined for } \\
\text { compliance. } \\
\text { Currently there is no legal obligation for the CBA to inform the RCUT of } \\
\text { suspicious transactions. There is a proposed change in the law to give the CBA } \\
\text { authority to exchange information on suspicious transactions with the RCUT } \\
\text { and this law should be passed. Now the CBA and RCUT meet twice a year to } \\
\text { discuss issues. }\end{array}$ \\
\hline & $\begin{array}{l}\text { Supervisory approach } \\
\text { An effective banking supervisory system requires that supervisors develop } \\
\text { and maintain a thorough understanding of the operations of individual banks } \\
\text { and banking groups, and also of banking system as a whole, focusing on } \\
\text { safety and soundness, and the stability of banking system. }\end{array}$ \\
\hline Description & $\begin{array}{l}\text { Essential criteria: } \\
\text { 1. CBA keeps for each individual company a company profile, which includes a } \\
\text { risk profile of the individual banks. The risk profile of each institution is based } \\
\text { on : } \\
\text { - The nature and size of its activities } \\
\text { - The legal structure } \\
\text { - Off site analysis } \\
\text { - Discussions with senior management } \\
\text { - Previous on site findings } \\
\text { - Professional judgment } \\
\text { Asset quality and non-performing loans are part of the risk profile assessment of } \\
\text { an institution, to the extent that they were part of the previous on site } \\
\text { examination. The CBA also has the RAST program available to assess the risk } \\
\text { profile of the banks. This program was formerly used by the Dutch Central } \\
\text { Bank. However, this program is outdated. CBA is contemplating implementing } \\
\text { the FIRM system, which is now applied by the Dutch Central Bank. This } \\
\text { program is risk based and can be applied to all financial sectors. } \\
\text { 2. CBA, through its regular analysis of prudential reports, regular on-site } \\
\text { examinations, meetings with senior management, and bankers' representative }\end{array}$ \\
\hline
\end{tabular}




\begin{tabular}{|c|c|}
\hline & $\begin{array}{l}\text { organization monitors and assesses trends, developments and risks for the } \\
\text { banking system as a whole. Also, the CBA has regular communication with the } \\
\text { home country supervisor of the onshore banks. CBA is responsible for the } \\
\text { supervision of the non-bank financial institutions (insurance companies, } \\
\text { pension funds and money transfer companies), which gives CBA direct access } \\
\text { to information on the developments in this sector. } \\
\text { 3. Refer to notes under criteria } 19 \text { (1) } \\
\text { 4. CBA assesses compliance with prudential regulations and other legal } \\
\text { requirements through regular review of the prudential reports, on-site } \\
\text { examinations and meeting with key staff. } \\
\text { 5. On basis of the SOSCS banks are required to notify CBA of any substantive } \\
\text { changes in their activities, structure and overall condition, or as soon as they } \\
\text { become aware of any material adverse developments, including breach of legal } \\
\text { or prudential requirements. } \\
\text { 6. CBA has an information system in place which is based largely on monthly } \\
\text { prudential returns. Reports are produced on an individual basis and aggregated } \\
\text { basis. These reports are used to monitor monetary and prudential requirements } \\
\text { of the individual banks and the banking sector as a whole. Secondary credit } \\
\text { institutions submit their prudential reports on a quarterly basis. } \\
\text { Additional criterion: } \\
\text { 1. At the moment CBA does not employ any defined methodology designed to } \\
\text { establish a forward-looking view on the risk profile of banks. }\end{array}$ \\
\hline & Largely compliant \\
\hline Comments & $\begin{array}{l}\text { See comments section of CP 8, credit risk. } \\
\text { The CBA is generally proactive in its supervisory approach with monthly } \\
\text { returns being submitted by credit institutions and annual on site examinations } \\
\text { for the systemically important commercial banks. The CBA collects a great deal } \\
\text { of data from banks, some of which is used for monetary policy purposes as } \\
\text { opposed to strictly supervision. } \\
\text { Given that Aruba's economy is concentrated on tourism and that tourism is } \\
\text { largely from the US, the banks' results often reflect the US economy's impact } \\
\text { on tourism. This, together with the fact that bank portfolios are largely retail } \\
\text { oriented and within a limited product range, the banking sector's performance is } \\
\text { often largely a function of external forces impacting the retail sector. } \\
\text { The CBA's approach to banking supervision continues to be largely compliance } \\
\text { oriented; compliance with key indicators and with laws and regulations. } \\
\text { This orientation is important and should continue but it needs to be expanded. }\end{array}$ \\
\hline
\end{tabular}




\begin{tabular}{|c|c|}
\hline & $\begin{array}{l}\text { Firstly, the data that is submitted on a monthly basis needs to be further refined } \\
\text { to provide supervisors with better information about the risk in banks. The } \\
\text { banks would also benefit from understanding how their data could be presented } \\
\text { and analyzed which would provide them with more risk oriented measures of } \\
\text { performance. This in turn could allow banks to better manage their various } \\
\text { risks, including large exposure limits, concentrations, interest rate risk, etc. }\end{array}$ \\
\hline Prin & $\begin{array}{l}\text { Supervisory techniques } \\
\text { An effective banking supervisory system should consist of on-site and off-site } \\
\text { supervision and regular contacts with bank management. }\end{array}$ \\
\hline Description & $\begin{array}{l}\text { Essential criteria: } \\
\text { 1. Section } 22,23,30 \text { and } 52 \text { of the SOSCS, provide CBA the legal basis for } \\
\text { collecting supervisory information and perform on-site supervision work. } \\
\text { Section } 22 \text { and } 30 \text { enables CBA to obtain respectively, the annual certified } \\
\text { annual accounts, and the monthly prudential reports. Per Section } 23 \text { of the } \\
\text { SOSCS, the CBA can monitor the quality of the work done by the external } \\
\text { auditors for supervisory purposes. The CBA has the authority to appoint } \\
\text { external auditors to conduct supervisory tasks. } \\
\text { By virtue of Section } 30 \text { of the SOSCS, banks must submit to CBA statements of } \\
\text { assets and liabilities and appendices, on a monthly basis. The appendices } \\
\text { include loan information by industry, large borrowers, liability maturity } \\
\text { schedules, maturity spreads of assets and liabilities, solvency analysis, etc. Loan } \\
\text { classification and provisioning is obtained on a quarterly basis (appendix } 12 / 13 \text { ) } \\
\text { during on site examinations and from the externally audited annual reports. } \\
\text { Section } 52 \text { authorizes CBA to request all information, demand inspection of all } \\
\text { books, records and other data carriers. It also provides right of entry to obtain } \\
\text { information and documents and establishes the authority for the performance of } \\
\text { on-site examinations. } \\
\text { The frequency with which CBA conducts regular on-site examinations at banks } \\
\text { it supervises depends to a large extent on the risk profile of each institution. } \\
\text { The risk profile of each institution is based on } \\
\text { - The nature and size of its activities } \\
\text { - The legal structure } \\
\text { - Off site analysis } \\
\text { institutions that CBA will visit on-site during a particular year. This schedule } \\
\text { shows the list of institutions that will be visited on-site, the (tentative) dates, } \\
\text { - Professional judgment }\end{array}$ \\
\hline
\end{tabular}


and the inspectors assigned for the specific on-site examinations. Preexamination planning consists of analysis of information received from prudential reports, results of meetings with bank senior management, and from the results of internal and external audits. Examiners assess the risk and issues and determine the scope of on-site work for the year.

On average, CBA plans on an annual basis 15 - 20 on-site visits that cover credit institutions, insurance companies, pension funds and money transfer companies. The on-site schedule is submitted to CBA management for approval. The institution is notified prior to the examination via a letter which lists the areas of examination and documents and information required.

Off-site monitoring involves the submission of various periodic reports such as monthly statements, quarterly statements (secondary banks) and the certified annual accounts. The returns are reviewed for compliance with requirements for, amongst others, capital adequacy, liquidity, monitoring large credit exposure.

CBA examination staff are assigned a portfolio of credit institutions. Therefore, they participate in both the onsite and offsite examination of their respective institutions. This enables them, and hence the supervisory authority, to have a full understanding of their respective institutions.

3. On-site examinations are conducted by staff-members of the Supervision Department. They are aimed at, inter alia, to review compliance with the law and regulations, provide independent verification that adequate risk management and internal controls systems are in place and to determine that the regulatory information provided is reliable. During its on site examinations CBA focuses on the main risk areas of a bank, namely quality of loan and investment portfolio, adequacy of loan loss provisions, the quality of AML/CFT policies, procedures and practices, and internal controls systems, including general computer controls.

During on site examinations, CBA meets with internal auditors and reviews their work program and its scope. Based on any findings as a result of the meeting with internal auditors, the scope of CBA's on site examination may expand. Preliminary on site findings related to internal controls are discussed with internal auditors prior to being discussed with senior management. Based on the findings, CBA may issue directives and/or guidelines.

More frequent inspections may be carried out if the risk profile indicates a need to do so.

CBA is in the process of outsourcing the on-site examinations of the offshore bank (Citibank Aruba N.V.). The on-site examinations will be conducted within a two-year cycle covering the following areas: 
- Compliance with AML/CFT laws and regulations;

- Review of the quality of the loan portfolio as well as the administrative organization and internal controls;

- Compliance with the corporate governance guidelines;

- IT-audit covering general computer controls;

- Review of the quality of the regulatory reports.

4. Off-site monitoring involves the submission of various periodic reports such as monthly statements, quarterly statements (secondary banks) and the certified annual accounts. Off site surveillance consists of analysis of monthly reports and appendices submitted by banks, the certified annual reports and management letters prepared by the external auditors. The returns are reviewed monthly for the financial condition of individual banks (e.g., capital adequacy, liquidity, monitoring large credit exposure). Other off-site supervision includes monitoring media and market place, exchanging information with other supervisors. Regular meetings with senior management of each bank are held at least twice a year, together with meetings involving the Aruban Bankers' Association.

5. CBA has regular contacts with senior and middle management mainly on issues relating with follow-up of on-site examination and reporting issues. It should be noted that CBA does not hold frequent contacts with bank's Board and audit committees to develop an understanding of and assess such matters as strategy, group structure, corporate governance, performance, capital adequacy and risk management systems.

6. The quality of the Board and management are assessed through review of the board and management minutes and regular meetings with the senior bank management. Operational matters such as group structure, corporate governance, performance, capital adequacy, liquidity, asset quality are discussed at these meetings. In addition, CBA currently holds meetings with the management of three of the four commercial banks to review strategic plans and budgetary issues.

7. CBA is able to place reasonable reliance on internal audit work that has been competently and independently performed. The quality and scope of internal audit is reviewed during on site examination.

8. After completion of the on-site examination the examiners team discusses the (preliminary) finding with the management. Subsequently, the findings are reported in writing to senior bank management.

Additional criteria:

1. CBA meets particularly with senior management to discuss the results of 


\begin{tabular}{|c|c|}
\hline & $\begin{array}{l}\text { supervisory examinations and the external audit. The CBA does not meet } \\
\text { separately with the Board. }\end{array}$ \\
\hline Assessment & Largely Compliant \\
\hline Comments & $\begin{array}{l}\text { The CBA's supervisory techniques are generally broad but additional depth is } \\
\text { needed. Generally, there is sufficient frequency of reporting and key areas of } \\
\text { risk are reviewed. The BCP assessors reviewed some onsite examination reports } \\
\text { as well as off site reports. The assessors found the reports to lack a desirable } \\
\text { level of analytical depth and a risk focus. Analysis needs to be enhanced and } \\
\text { should involve more than changes in key statistics from period to period. The } \\
\text { underlying reasons for changes need to be analyzed and understood. A starting } \\
\text { point is the require better information from the banks on the various risk areas } \\
\text { mentioned in this BCP assessment. In addition, the supervisors, and likely the } \\
\text { bankers as well, would benefit from training in financial analysis techniques. } \\
\text { The CBA should have more frequent contacts with bank's Board and audit } \\
\text { committees to develop an understanding of and assess such matters as strategy, } \\
\text { group structure, corporate governance, performance, capital adequacy and risk } \\
\text { management systems. } \\
\text { The outsourcing of the examination of the offshore banks needs to have an } \\
\text { expanded scope to cover market risk and all other relevant risks. . }\end{array}$ \\
\hline & $\begin{array}{l}\text { Supervisory reporting } \\
\text { Supervisors must have a means of collecting, reviewing and analyzing } \\
\text { prudential reports and statistical returns from banks on both a solo and a } \\
\text { consolidated basis, and a means of independent verification of these reports, } \\
\text { through either on-site examinations or use of external experts. }\end{array}$ \\
\hline Des & $\begin{array}{l}\text { Essential criteria: } \\
\text { 1. By virtue of Section } 30 \text { of the SOSCS, banks must submit to CBA, on both a } \\
\text { solo and a consolidated basis, statements of assets and liabilities and appendices } \\
\text { on a monthly basis. The appendices include loan information by industry, large } \\
\text { borrowers, liability maturity schedules, maturity spreads of assets and } \\
\text { liabilities, capital adequacy, liquidity, large exposures, asset concentration, non- } \\
\text { performing loans, loan provisioning, related party transactions, country, interest } \\
\text { and foreign exchange risks. Instructions for the prudential returns state that each } \\
\text { return must be submitted to CBA within } 15 \text { working days of each month end. } \\
\text { Furthermore, in accordance with section } 30 \text { (1) the monthly statement of the } \\
\text { month of December must be certified by an external auditor. } \\
\text { In addition by virtue of section } 22 \text {, each credit institution is required to submit } \\
\text { to CBA, within six months after the end of the financial year, its annual } \\
\text { accounts, accompanied by the external auditor's report. } \\
\text { 2. According to section } 22 \text { (1) CBA has the authority to establish accounting } \\
\text { principles and norms to be used in consolidation of annual accounts as well as }\end{array}$ \\
\hline
\end{tabular}


the accounting techniques to be used. However, the CBA has not issued specific guidelines for the annual accounts. The banks apply international accounting standards (IFRS).

With respect to the monthly returns, CBA has issued guidelines for the preparation of the monthly Statements (MS) and appendices, which banks have to adhere to. According to these guidelines the assets and liabilities should be stated at book value.

3. Although CBA has not issued explicit guidelines in this area since all credit institutions apply IFRS or Dutch Gaap. Note also that CBA is revising the regulatory reports in order to bring them more in line with IFRS. This project is done in cooperation with the BNA. The Dutch Central Bank (DNB) is also providing technical assistance with respect to this project.

4. CBA collects and analyses information from the commercial banks on a monthly basis, while the other bank-like institutions report on a quarterly basis. CBA has an analytical framework that uses the statistical and prudential information for the ongoing monitoring of the condition and performance of individual banks and on an aggregated basis. Also, all credit institutions are required on the basis of section 22 to submit their certified annual accounts. Refer to notes under criteria 21 (1).

It should be noted that the CBA has installed a project group to design and implement a new standard reporting framework for commercial banks (chart of accounts). In this respect, it was decided to work together with the Central Bank of Netherlands Antilles (BNA) on this matter. The onshore commercial banks are subsidiaries or branches of Antillean banks and the implementation of such large and complex project would benefit both entities. The new standard reporting forms will have to comply with the basic concepts and principles of Monetary and Financial Statistics Manual 2000 of the IMF, as well as the IFRS and Basel II capital requirements (standardized approach)

5. In accordance with section 31 of the SOSCS the regular reports should contain information both on a solo and consolidated basis.

6. In accordance with section 52 of the SOSCS, CBA is authorized to request all information, demand inspection of all books records and other data carriers. Also, it is authorized to enter all places, if necessary with the aid of the police.

7. Refer to notes under criteria 21 (6)

8. Sections 30 through 33 of the SOSCS grant CBA the means to enforce compliance. Under Section 53, a credit institution acting in violation of the above-mentioned provisions shall be liable either to imprisonment or fine. However, CBA does not have the legal authority to impose administrative 


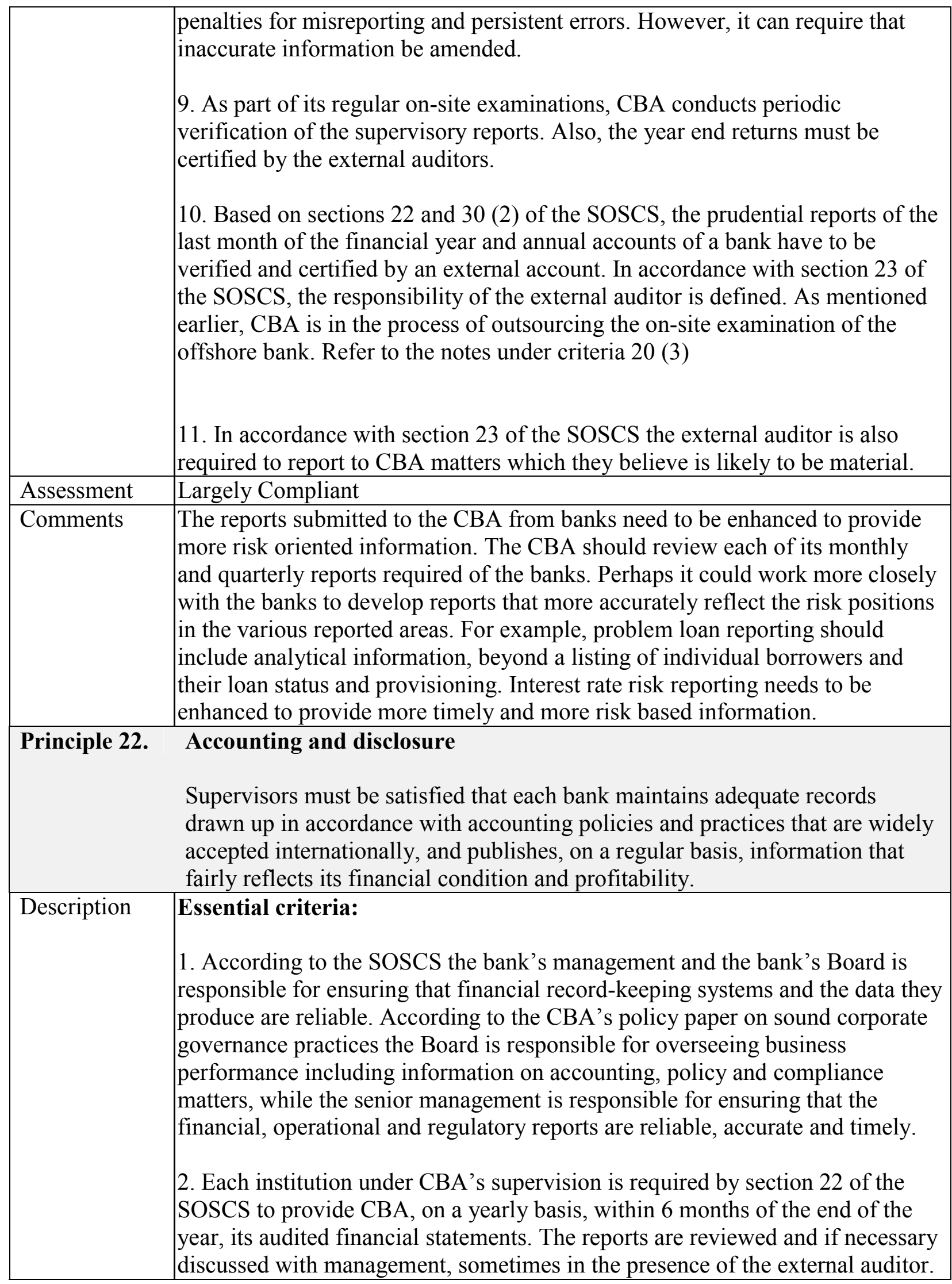


The annual financial statements bear an external auditor's opinion.

In general, financial statements are prepared in accordance with IAS. CBA ensures that information from bank records is verified periodically through onsite examinations and/or external audits. By virtue of Section 23 of the SOSCS, CBA ensures that there are open lines of communication with external auditors.

3. The CBA has not issued explicit guidelines in this area since all credit institutions apply IFRS or Dutch Gaap. Note also that CBA is revising the regulatory reports in order to bring them more in line with IFRS. This project is done in cooperation with the BNA. The Dutch Central Bank (DNB) is also providing technical assistance with respect to this project.

4. CBA does not have the authority to establish the scope of external audits in individual banks. In order to have audit scopes address issues of particular interest to CBA, it would need to go through the banks to have them make the request to their auditors. This is regulated in section 23 (2) of the SOSCS. Herein the responsibility of the external accountant is defined. According to this section when granting the external auditor the assignment to audit the annual accounts, the credit institution shall instruct its auditor in writing to, after consultation with the credit institution, to provide the CBA with a copy of the auditors report to Board, letters to management and other relevant correspondences.

5. CBA has issued explicit guidelines covering areas such as the loan portfolio, loan loss reserves, and non-performing assets, all other areas (asset valuations, trading and other securities activities, derivatives, asset securitizations).

6. On basis of the directive on the appointment of an external auditor for any appointment of, change in external auditor, CBA's prior written approval is required. However, it does not have the authority to reject and rescind the appointment of an external auditor on its own authority. The CBA should also be informed on the reasons of the intended change. In this respect, the CBA might reject and rescind the appointment of an external auditor which is deemed to have inadequate expertise or independence or is not subject to or has not follow established professional standards. In accordance with section 1 (1) the auditor must be registered at the Netherlands Institute of Chartered Accountants or elsewhere at a similar institute as the Netherlands Institute of Chartered accountants, and is subject, in opinion of the CBA, to a similar regime of rules of conduct, professional code and discipline.

7. CBA requires banks to produce annual audited financial statements based on IAS. The statements are audited under IFRS, although this is not CBA's requirement. As mentioned earlier it is the intention to implement in the future a new standard reporting framework (chart of accounts or COA) for commercial 
banks. The COA will be based on the basic concepts and principles of the IMF's Monetary and Financial statistics manual 2000, as well as the IFRS and Basel II capital guidelines (standardized approach).

8. In accordance with Section 76 of the Code of Commerce, each financial institution has to submit its condensed financial statement to the Chamber of Commerce to enable the public to have access to them. In this respect, CBA has issued a supervisory directive on the publication of the audited financial statements which requires all credit institutions to publish their annual financial statements or (for CBA acceptable) extract thereof within 6 months after the end of the financial year by filing subject statements with the Chamber of Commerce. Branches are required to publish the audited financial statements of the legal entity of which they form part. CBA directive on the disclosure of financial statements was issued by virtue of section 15 (1) of the SOSCS.

9. The required disclosure is only limited to the financials performance and financial position. The credit institutions are not required to report on the other areas (such as risk management strategies and practices, risk exposures, transactions to related parties and governance).

10. CBA directive on the disclosure of financial statements was issued by virtue of section 15 (1) of the SOSCS. This requires that the bank have to comply with the disclosure standards. The adequacy of disclosure is confirmed during on site inspections.

11. CBA publishes aggregate information on the banking system on an annual basis. This information is published in the $4^{\text {th }}$ quarter bulletin of CBA and Annual Report. Such information includes aggregate data on balance sheet, profit \& losses, and core prudential indicators.

\section{Additional criteria:}

1. CBA does meet with external auditors to discuss issues of common interest relating to bank operations. This is done by on a case-by-case basis.

2. Auditors have the legal duty to report to the supervisor matters of material significance, including failure to maintain the licensing criteria, or breaches of banking or other laws. The law protects auditors from breach of confidentiality when information is communicated in good faith. Auditors also have the legal duty to report matters to the supervisor, which they believe, are likely to be of material significance to the functions of CBA (section 23 (2) SOSCS).

3. The SOSCS does not require banks to rotate their external auditors.

4. Refer to notes under $22(8)$ 


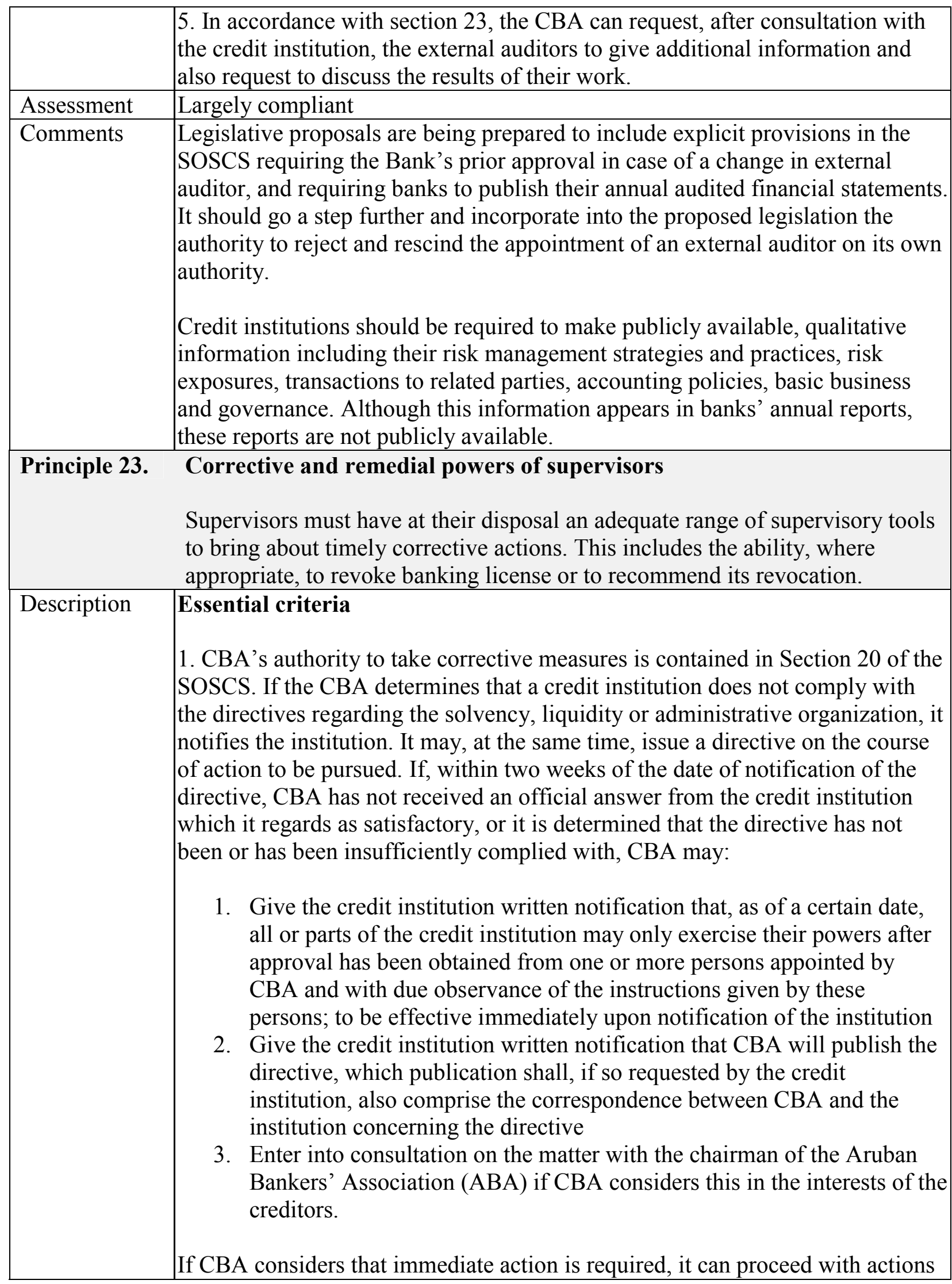




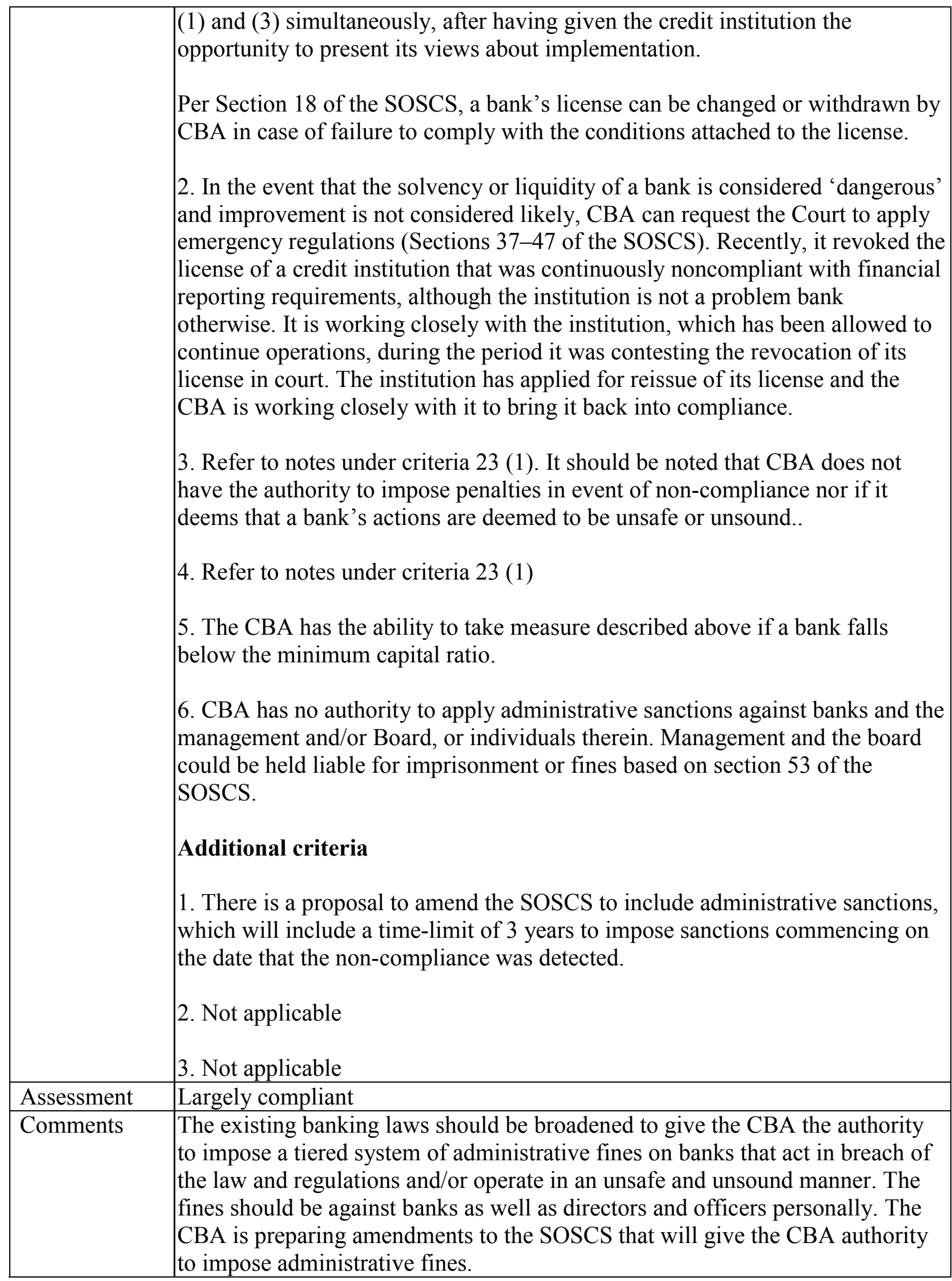




\begin{tabular}{|c|c|}
\hline & $\begin{array}{l}\text { Consolidated supervision } \\
\text { An essential element of banking supervision is that supervisors supervise } \\
\text { banking group on a consolidated basis, adequately monitoring and, as } \\
\text { appropriate, applying prudential norms to all aspects of the business } \\
\text { conducted by the group worldwide. }\end{array}$ \\
\hline Desc & $\begin{array}{l}\text { Essential criteria: } \\
\text { 1. None of the locally incorporated banks have foreign branches and } \\
\text { subsidiaries. } \\
\text { 2. CBA does have the legal power to review the overall activities of a banking } \\
\text { group, both domestic and cross-border if required. In accordance with Section } \\
\text { 24 of the SOSCS, branches of foreign banks have to comply with the same } \\
\text { requirements as domestic banks. The CBA is knowledgeable about the } \\
\text { approach and scope of the supervision conducted by the home country } \\
\text { supervisors, the U.S. Fed and OCC. The local operations of foreign banks are } \\
\text { the offshore Citibank operations, whose operations were 'grand fathered' due to } \\
\text { their long-standing presence here. } \\
\text { 3. CBA has, on basis of the SOSCS, the framework to evaluate the risks that } \\
\text { non-banking activities conducted by a bank or banking group may pose to the } \\
\text { bank or banking group. } \\
\text { 4. In accordance with section } 31 \text { of the SOSCS regular reports to CBA should } \\
\text { contain information both on a solo and consolidated basis. All the existing } \\
\text { prudential standards can be applied on a consolidated basis to cover such areas } \\
\text { as capital adequacy, large exposures, exposures to related parties and lending } \\
\text { limits } \\
\text { 10. Not applicable } \\
\text { 5. The CBA has signed a MOU with the BNA (refer to notes under } 25 \text { (4)). } \\
\text { 6. Not applicable } \\
\text { 7. Not applicable } \\
\text { impose limitations on their activities. } \\
\text { 10 }\end{array}$ \\
\hline
\end{tabular}




\begin{tabular}{|c|c|}
\hline & $\begin{array}{l}\text { 2. Not applicable } \\
\text { 3. Not applicable }\end{array}$ \\
\hline Assessment & Not applicable \\
\hline Comments & $\begin{array}{l}\text { None of the locally incorporated banks have local or foreign branches or } \\
\text { subsidiaries. }\end{array}$ \\
\hline Principle 25. & $\begin{array}{l}\text { Home-host relationships } \\
\text { Cross-border consolidated supervision requires cooperation and information } \\
\text { exchange between home supervisors and the various other supervisors } \\
\text { involved, primarily host banking supervisors. Banking supervisors must } \\
\text { require the local operations of foreign banks to the same standards as those } \\
\text { required of domestic institutions. }\end{array}$ \\
\hline Description & $\begin{array}{l}\text { Essential criteria: } \\
\text { 1. Section } 34 \text { of the SOSCS provides the possibility for information exchange } \\
\text { between CBA and foreign supervisors provided that: } \\
\text { - furnishing of the information is not contrary to the interests the SOSCS } \\
\text { is seeking to protect; } \\
\text { CBA has ascertained the purpose for which the information shall be } \\
\text { used, and } \\
\text { it is sufficiently guaranteed that the information shall not be used for } \\
\text { - ther purposes; } \\
\text { - the information can be exchanged on a basis of reciprocity. } \\
\text { 2. Not applicable. Aruban banks do not have overseas operations. } \\
\text { 3. Not applicable. Refer to notes under criteria } 25 \text { (2) } \\
\text { 4. CBA has maintains close contact with Central Bank of the Netherlands } \\
\text { Antilles (BNA), which is the home supervisor of all the onshore commercial } \\
\text { banks operating in Aruba. Regular meetings are held between the two } \\
\text { institutions to discuss issues of mutual interest, including supervisory issues. } \\
\text { CBA has signed two MOU's with the BNA on the exchange of information on } \\
\text { banks and insurers. } \\
\text { On the other hand, Citibank Aruba N.V. was an exception and was } \\
\text { grandfathered due to its long-standing presence in Aruba. Although there is no } \\
\text { formal MOU with the US financial regulatory authorities, information } \\
\text { exchanges have taken place between CBA on the one hand and the Federal } \\
\text { Reserve Board and the Office of the Comptroller of the Currency on the other, } \\
\text { with respect to the two offshore banks established in Aruba. The basis for this } \\
\text { information exchange was provided by a formal exchange of letters confirming }\end{array}$ \\
\hline
\end{tabular}




\begin{tabular}{|c|c|}
\hline & $\begin{array}{l}\text { the willingness of the parties concerned to provide each other with supervisory } \\
\text { information regarding the two offshore banks. This procedure has proved } \\
\text { satisfactory to all three parties concerned. } \\
\text { In August 2006, CBA also became party to a Multilateral Memorandum of } \\
\text { Understanding (MMOU) on cross-border cooperation and information } \\
\text { exchange between several supervisory authorities within the Caribbean region. } \\
\text { The increasing cross-border activities of regional financial groups have } \\
\text { increased the need for enhanced regional cooperation and information exchange } \\
\text { with respect to these financial groups and were the driving force for establishing } \\
\text { this MMOU. At present discussions are taking place within the Caribbean } \\
\text { Group of Banking Supervisors to increase the effectiveness of said MMOU by } \\
\text { adding operational protocols for information exchange. } \\
\text { 5. In accordance with Section } 24 \text { of the SOSCS, branches of foreign banks have } \\
\text { to comply with the same requirements as domestic banks. } \\
\text { 6. According the CBA's revised admission and licensing policy, before issuing } \\
\text { a license the home country supervisor must give a statement of no objection and } \\
\text { the CBA ascertains that the home country supervisor practices effective global } \\
\text { consolidated supervision. } \\
\text { 7. Not applicable } \\
\text { 8. Not applicable } \\
\text { 9. The CBA will consult with other supervisors to the extent possible before } \\
\text { taking consequential action on basis of information received from another } \\
\text { supervisor. Refer to notes under criteria } 25 \text { (1) } \\
\text { 1. Not applicable }\end{array}$ \\
\hline Assessment & Compliant \\
\hline Comments & None \\
\hline
\end{tabular}

